Article

\title{
Overselling Globalization: The Misleading Conflation of Economic Globalization and Immigration, and the Subsequent Backlash
}

\author{
Ernesto Castañeda ${ }^{1, *(D)}$ and Amber Shemesh ${ }^{2}$ \\ 1 Department of Sociology, American University, Washington, DC 20016, USA \\ 2 School of International Service, American University, Washington, DC 20016, USA; as6103a@american.edu \\ * Correspondence: ernesto@american.edu
}

Received: 20 January 2020; Accepted: 22 April 2020; Published: 26 April 2020

check for updates

\begin{abstract}
Many think that immigration is something caused by globalization, and some subsequently blame immigrants for the increased inequalities produced by economic globalization. Xenophobic nationalism has gained popularity around the world, further increasing racial tensions but without addressing the underlying causes of growing socioeconomic inequality, which this paper strives to show is caused by economic policies, not immigration. This paper argues that the apparent retreat from globalization arises from the flawed conceptualization of "globalization" as a bundle of different processes. This study analyzes early framings of economic globalization and shows how it has been linked, for political reasons, to increased migration, diversity, and open borders. Coining the term "globalization" was not just naming ongoing social change, but it became part of the branding of an elite ideological policy project. The popular framing of globalization purposely entangled independent phenomena such as free trade policies, the expansion of the internet, cosmopolitan identities, and international migration. These couplings brought together neoliberal conservatives and liberal cosmopolitans. Given the current backlash, it is essential to distinguish migration from policies favoring trade and capital movement across borders. It is noteworthy to remember that immigration is something that preceded globalization. Therefore, it is necessary to investigate how migration became entangled with globalization in the popular imagination.
\end{abstract}

Keywords: anti-immigration; neoliberalism; populism; xenophobia; globalists; borders

\section{Introduction}

Globalization is a concept that is widely discussed yet hardly defined. No singular, concise definition is agreed upon by all scholars. A consensus, though, is that the term is rooted in changes in economic policy. However, globalization's definition has been increasingly expansive-by, for example, including people and culture in the list of cross-border exchanges. No discipline owns the term or has sole jurisdiction over the study of "the global" (Koos and Keulman 2019). The term has become obfuscated, obscuring rather than clarifying social analyses.

It is common today to use the term "globalization" in everyday language and assume that there is a shared meaning, but the term is polysemic; it means different things to different people. This paper presents a brief analysis of how the academic definitions of globalization have varied through the years, and how those definitions have altered the general public's notion of what the implications of globalization are for them. The paper theorizes about the contemporary political consequences of the most popular framings of the term globalization and especially, its conflation with international migration and cultural homogenization.

The public has been told for decades that there is a direct link between globalization and immigration. This paper analyzes early framings of economic globalization and shows how some social 
theorists, politicians, and pundits linked economic liberalization to increased migration, diversity, and open borders. Theorists oversold globalization to draw attention to the magnitude of the changes to come. The popularized framing of globalization entangled independent phenomena such as free trade policies, offshoring, the expansion of the internet, cosmopolitan identities, and international migration into one. This conflation was embraced for political reasons by the left and right alike. Coining the term "globalization" was not just denoting ongoing social change, but it became the branding of a policy project while its consequences were starting to unfold. Like a financial derivative, the concept of globalization packaged together fragments of independent objects and branded them as desirable investments. As with many derivatives after the 2008 recession, the globalization combo seemed less appealing after the shrinking of the middle class.

Research shows that income and wealth inequalities have increased in the last four decades (Case and Deaton 2020; Keister 2014; Killewald et al. 2017; Piketty and Saez 2003; Piketty 2014). In the United States, the 1 percent with the highest earnings received about 20 percent of total income in 2011, up from about 10 percent in the late 1970s (Alvaredo et al. 2013, p. 4), and "since 1981, the incomes of the top $5 \%$ of earners have increased faster than the incomes of other families" (Horowitz et al. 2020). However, rather than attacking the fiscal policies and practices causing this growing inequality, "globalization" at large has been blamed. Opportunistic politicians and parts of the population blamed the decrease in wages and employment security brought up by neoliberal economic policies linked to globalization on immigrants and ethnic minorities. In recent years, xenophobia and nationalism have gained popularity around the world, further increasing racial tensions without addressing the causes of growing socioeconomic inequality, creating more space for the radicalization of white nationalists. For example, Donald Trump's first presidential campaign attacked "globalization" for its effects in the domestic job market. He equated globalization with China and immigration with Mexico. He blamed them directly for deindustrialization and a decreasing standard of living among the white working-class. However, he failed to mention the fact that U.S. corporations and shareholders have been some of the largest beneficiaries of access to cheap labor at home and abroad.

While social spending and policies put in place during the New Deal have been rolled back, migration patterns have not changed in terms of relative magnitude. Nonetheless, popular discourses often reproduce this confounding of globalization and migration. It is essential to distinguish between the movement of people and the policies favoring international trade and capital flows. The apparent retreat of globalization arises from the framing of the term "globalization," by epistemological debates and political posturing, rather than by fundamental changes in international trade or population dynamics in the last years. Open borders have never been the explicit goal of the North American Free Trade Agreement (NAFTA) or the renegotiated United States-Mexico-Canada Agreement (USMCA). In the cases where opening borders to trade have been linked to the free movement of people, e.g., within the European Union, no migration crises have occurred because only a small percentage of European citizens have migrated within the region (Crouch 2019, p. 23).

The percentage of migrants in the world in 2017 was approximately 3.4 percent of the population (UN 2017), and this is consistent with previous years (Koser 2007). Since 1850, the percentage of the foreign-born in the United States of America has fluctuated between a low of 4.7 percent of the population in 1970 to highs of 14.8 percent in the 1890 and 13.6 in 2017 (Radford 2019). Undocumented immigrants in the United States were approximately 3.2 percent of the U.S. population in 2017 (Radford 2019). Detentions at the U.S. border have gone down since 2000 (Massey 2019). Since 2008, more Mexicans are leaving the U.S. than arriving (Passel et al. 2012). The most significant new sources of immigrants to the United States are El Salvador, Guatemala, and Honduras. However, these countries have a combined total population of 33 million in 2017 versus a U.S. population of 325.7 million, and clearly, not all Central Americans want to leave their homes and move to the U.S.

As of February 1, 2020, the European Union was composed of 28 member countries, including the U.K, with a population of at least 512.4 million people. According to Eurostat, in 2017, 4.4 million people immigrated to one of the then 28 member countries of the European Union, and at least 
3.1 million people left a member country. Therefore, net migration was approximately 1.3 million or 0.25 percent of the EU population, a rather negligible percent for labor markets and welfare systems, even more, because most migrants work, pay taxes, and consume goods. In 2018, 22.3 million EU residents were non-EU citizens, that is, $4.4 \%$ of the population. Despite completely open internal borders, in 2018, only "1.9 million people previously residing in one EU Member State migrated to another Member State"(Eurostat 2020), which is only 0.37 percent of the population. The civil war in Syria had produced 6.7 million refugees as of 2018 (Todd 2019), and, while tragic, this represents less than 0.1 percent of a global population of 7.53 billion. Each number represents a difficult departure for these individuals. Some countries receive more immigrants and refugees than others. Nevertheless, these numbers show that the vast majority of the world population is not migrating (Koser 2007).

Therefore, numerically and globally speaking, the numbers of international migrants should not be panic-inducing. How did ongoing migration processes become entangled with a series of supposedly novel phenomena? How did a term that was initially understood as a movement of goods become conflated with the movement of people? What is the actual link between globalization and migration? This paper analyzes academic and political discussions around immigration and globalization, but first, the meaning of "globalization" must be considered.

\section{What Is Globalization?}

Goods and services consumed by people have always come from a combination of local, nearby, and distant sources. The changes in international trade routes, war, technology, and production affect this mix. Thus, American social theorist, Charles Tilly describes globalization as an increase in the proportion and impact of intercontinental over local or regional transactions (Tilly 1995, pp. 1-2). In other words, Tilly means that sometimes people will be more likely to trade and form relationships with people far away (e.g., populations living close to roads leading to Rome during the Roman Empire, or the historical silk route). At other times, economic transactions and local ties will be more local and regional (e.g., during civil wars, sieges, blockades, famines, quarantines, or during the times of import substitution industrialization, the iron wall, or Cuba under embargo). At other times people will be the ones moving (Castañeda 2018a). In Figure 1, it can be seen how Tilly graphs levels of globalization along two axes: The impact (magnitude and social significance) of intercontinental (long-distance, e.g., between America and Europe, or Asia and Africa) transactions (trade, communication, association, contracts, relationships, alliances, marriages, etc.) versus the proportion (number of intercontinental transactions/local transactions) of intercontinental transactions. Some products and services must be local such as haircuts, delivery, garbage collection, dry cleaning, landscaping, restaurants, and other services. In contrast, others can be either local, regional, or international, e.g., food and industrial production.

Tilly sees this as a two-directional process (Figure 1). Quantitatively more intercontinental trade and qualitatively more meaningful exchanges lead to high levels of globalization. The increases in local consumption and decreases in the impact and number of international trade lead to deglobalization or a low level of globalization. Thus, for Tilly, "globalization" is not a thing or era-defining phenomenon but a temporal state of affairs regarding the geographical scale of frequent economic and social relations. Significant changes in the social importance and ratios between local and distant production and consumption have occurred before. The process of globalization in trade has manifested itself various times throughout history. Therefore, historically-minded scholars talk about large waves of globalization in modern times. 


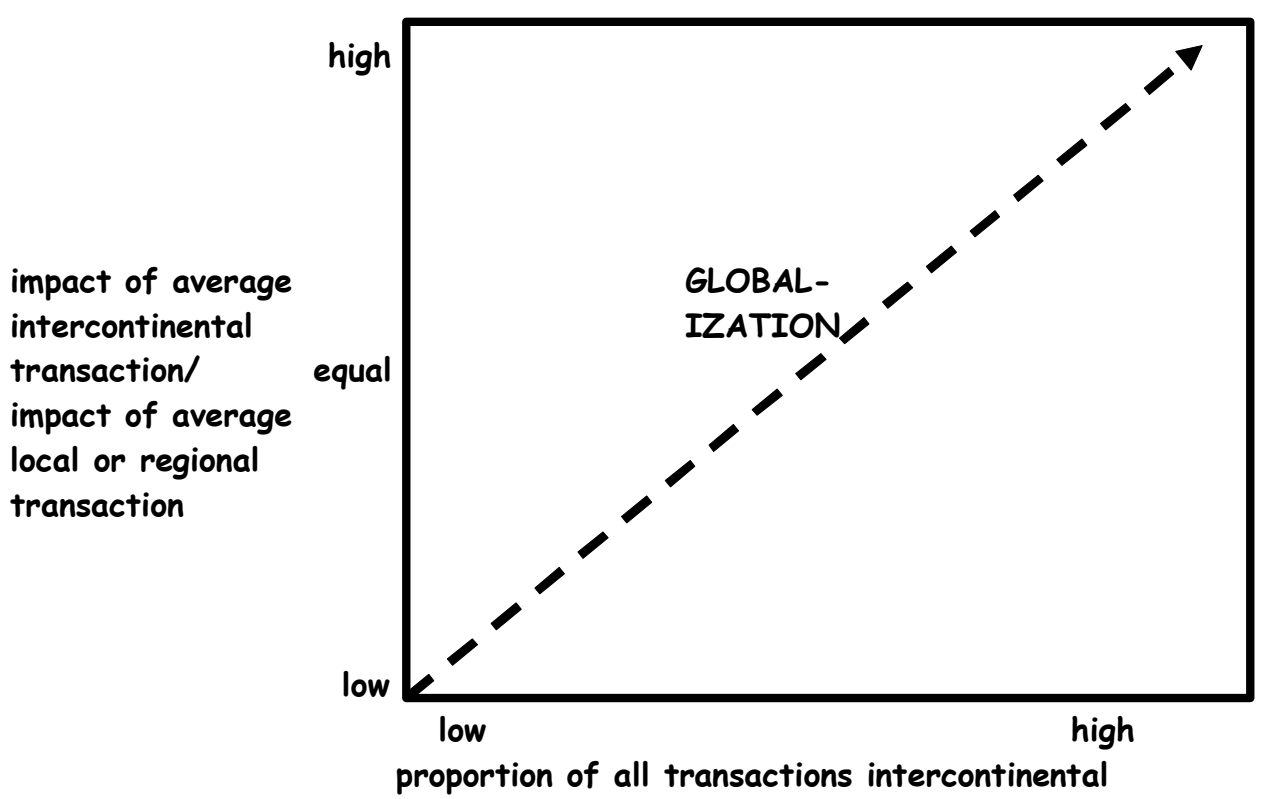

Figure 1. The process of globalization and deglobalization (source Castañeda 2007).

\section{Waves of Globalization}

Many authors agree that economic "globalization" has occurred before. During colonialism and the Industrial Revolution in the nineteenth century, companies used raw materials from faraway lands and desperately looked for markets abroad. In 1820, "café-goers would sip Chinese tea sweetened with Jamaican sugar" (The Economist 2016). While the term globalization itself may not have been used at the time of the Industrial Revolution, the process of globalization, as defined above, is clear. Though an exact periodization is hard to pin down, globalization happened before.

According to some, there have been two periods of globalization: "One from the end of the Napoleonic Wars [1803-1815] to World War One, and the other from the end of World War Two to the present" (Bardhan et al. 2006, p. 3). Going further back to the 1500s, Charles Tilly argues that globalization has occurred in three waves:

During the half millennium since 1500, three main waves of globalization have occurred. The first arrived right around 1500. It resulted from the rapidly spreading influence of Europe, growth of the Ottoman Empire, and parallel expansions of Chinese and Arab merchants into the Indian Ocean and the Pacific ... We can place the second major post-1500 wave of globalization at approximately 1850-1914 ... During this period, international trade and capital flows reached previously unmatched heights, especially across the Atlantic ... Migration, trade, and capital flows slowed between the two world wars. But as Europe and Asia recovered from World War II, a third post-1500 surge of globalization began ... During the early twenty-first century, the third wave of post-1500 globalization was moving ahead with full force (Tilly et al. 2020, pp. 99-100).

Tilly does not mean to say that globalization comes in waves, as the effects of changes in the ocean or as a force of nature producing waves following its own rhythm. Instead, Tilly argues that there have been periods of high globalization even before this term emerged. He also indicates that war and epidemics have caused low levels of globalization in the past (Tilly et al. 2020, Chapter 5).

Some use the term "global" as a western-centric euphemism for imperialism and colonialism (Friedman 2005; Poppi and Cheng 2013, p. ix), with the first wave beginning with Christopher Columbus' trip across the Atlantic Ocean. Friedman uses celebratory and anachronistic language to describe previous waves of globalization. His characterization of the current wave of globalization tends to be too focused on individual agency and technological change. It repeats many of the clichés associated 
with the term "globalization," as discussed below. Claims abound that the last wave of globalization has been "powered by individuals, who began to cooperate globally, thanks to the creation and diffusion of a global fiber-optic network all over the world" (Poppi and Cheng 2013, p. ix). The increases in technological advances have indeed created the possibility for faster methods of communication across long distances. However, the widely held assumption that these new technologies caused globalization is wrong. Saying that new technologies cause globalization is what Tilly calls technological determinism, that is, attributing outsized causal power to technology without looking at the social conditions that precipitate the adoption and spread of technology affecting production and consumption. Furthermore, new technologies emerge constantly, and technology does not necessarily disappear in times of deglobalization.

In his 1979 book, The Capitalist World-Economy, Immanuel Wallerstein does not use the term globalization. Instead, he discusses the long-distance trade and conceptions of economic growth surrounding the Industrial Revolution. He argues:

In the mid twentieth century, the dominant theory of development in the core countries of the capitalist world-economy had added little to the theorizing of the nineteenth-century progenitors of this mode of analysis, except to quantify the models and to abstract them still further, by adding on epicyclical codas to the models in order to account for ever further deviations from empirical expectations (Wallerstein 1979, p. 2).

Thus, the answer to what is globalization is not to be found in economics textbooks, but in the historical record and the history of ideas.

\section{Coining the Term}

The term "globalization" spread relatively quickly from business school discussions to academia, to popular publications read by some aspiring policymakers, and to public policy. The Economist is an influential British magazine that has long acted as a proponent of free trade, neoliberal policies, and economic globalization. The magazine's first use of the term "globalization" was in an article in 1961 arguing for economic reform in Spain. Nonetheless, it was not until 1983 when Theodore Levitt became one of the first scholars to define the term. A marketing professor at Harvard Business School, Levitt used "globalization" to "refer to the spread of corporations around the world" and "the more or less simultaneous marketing and sale of identical goods and services around the world" in an article in the Harvard Business Review (The Economist 2009).

Levitt argued that it is beneficial for companies to "globalize," that is, to standardize their products and expand their geographical reach rather than focus on local product specialization. He described this process as a necessary means to improve overall productivity and saw the advancement of technology as a way to achieve this standardization. He then made a forecast:

The globalization of markets is at hand. With that, the multinational commercial world nears its end, and so does the multinational corporation. The multinational and the global corporation are not the same thing. The multinational corporation operates in a number of countries, and adjusts its products and practices in each-at high relative costs. The global corporation operates with resolute constancy-at low relative cost-as if the entire world (or major regions of it) were a single entity; it sells the same things in the same way everywhere (Levitt 1983).

For a while, it was common for companies such as Colgate-Palmolive to produce different products, for example, making different kinds of toothpaste in Mexico and the United States, with physical factories, workers, media campaigns, and different formulas in each country. Levitt proposed to standardize the product entirely. Levitt's argument in favor of product standardization worldwide has been actualized by corporations standardizing "products, packaging, and communication to achieve a least-common-denominator positioning that would be effective across cultures" (Holt et al. 2004). 
Levitt's ideas, in large part, reflected ongoing practices by corporations-such as Coca-Cola—using global brands and marketing campaigns and became adopted by a few others in the 1980s.

Subsequently, McDonald's evolved into both a favorite example and proof of globalization. Soon the implications of product standardization across some countries became increasingly exaggerated and unproven. However, they became a mantra and part of an invisible ideology for generations. Many sociology books included McDonald's in their title and talked about large social change. Time writer Randy James writes that McDonald's is "widely seen as one of the true vanguards of peaceful globalization" due to the corporation's 1990 opening in Moscow, which he says is "credited with helping thaw Cold War tensions" (James 2009). James cites the columnist Thomas Friedman, who "has asserted that nations with McDonald's locations do not go to war with each other-the so-called Golden Arches Theory of Conflict Prevention-although that thesis notably collapsed in the case of the 2008 war between Russia and Georgia"(James 2009). Additionally, Friedman wrote:

The world has become an increasingly interwoven place, and today, whether you are a company or a country, your threats and opportunities increasingly derive from who you are connected to. This globalization system is also characterized by a single word: the Web. So in the broadest sense we have gone from a system built around division and walls to a system increasingly built around integration and webs (Friedman 1999, p. 8).

Thus, many of the new words of the late 1990s and early 2000s used to discuss the internet-web, interwoven, connected, integrated - could be put together in one paragraph to describe changes to come in the economy and social relations across long distances. Nonetheless, having people communicate and connect through the internet is not truly equivalent to eliminating tariffs or visas. Furthermore, to whom one is connected to has always had the most significant implications, as argued by sociologists and others using a relational understanding (Bandelj 2012; Castañeda 2018b; Mische 2011; Padgett and Ansell 1993; Simmel 1964; Tilly et al. 1995; Zelizer 2012).

Fast-food franchises require local inputs and personnel. However, when it comes to manufacturing, globalization can lead to the outsourcing of production, increases in imports, and the closing of local factories. Neoliberal economists frame this in terms of national "competitive advantages," which in practice is a way to justify moving factories to countries with cheaper labor and weaker labor laws. Offshoring can increase unemployment and reduce wages for former industrial workers in developed and middle-income countries.

\section{The Role of Social Theorists in an Expanding Conception of Globalization}

British sociologist Anthony Giddens writes about how globalization brings up issues of scale that go beyond "societies" and national borders. Giddens defines globalization "as the intensification of worldwide social relations which link distant localities in such a way that local happenings are shaped by events occurring many miles away and vice versa" (Giddens 1990, p. 64). Giddens describes globalization as a dialectical process because the global impacts the local and the local becomes part of the global. In the words of Michael Lang, Giddens defines globalization as the "stretching of social connections between the local and the distant so as to create a highly intensified worldwide scale"(Lang 2006, p. 900). According to Giddens, globalization has social implications and broadens the scope of relations among societies and individuals across the world. Giddens sees globalization as a radicalization of the properties of modernity. In the words of Hsu, for Giddens:

globalization does not wholly supersede previous forms of social organization; globalization is not only associated with the blurring of traditional distinctions such as what is international or domestic, but it is also linked to the reiteration of some of those features ... Such a nuanced approach is absent from the hyperglobalists and the skeptics, who both tend to approach globalization as an either/or proposition (Hsu 2010, p. 207).

While some authors, such as those presented below, proposed quite nuanced and complicated views of globalization, many citizens were quick to divide into anti- and pro-globalization camps with 
corresponding moral attributes. Not only were financiers, tech entrepreneurs, politicians, pundits, journalists, and students enamored by the new term "globalization" and the futurist images it produced, but so were serious social theorists, including critical ones.

Karl Marx wrote explicitly about the global nature of capitalism and how it needed to expand territorially to continue existing. He also wrote about how this would create new dispossessions and systemic crises (Tucker 1978). Nonetheless, social theorists tried to explain the new twists in the global expansion of capitalism happening around them. For instance, being based in the multicultural San Francisco Bay Area in the 1990s, University of California Berkeley sociologist Manuel Castells wrote much about what he called "the networked society" and the "new information economy." His brilliant analysis and observations though conflated changes in the economy, innovation in communication technologies, and migration in his three-volume classic work The Information Age: Economy, Society and Culture (Castells 1986, 1987, 1988). Castells writes:

In the last quarter of this century, a new form of socio-economic organization has emerged ... it is certainly a capitalist system. Indeed, for the first time in history the entire planet is capitalist, since even the few remaining command economies are surviving or developing through their linkages to global, capitalist markets. Yet this is a brand of capitalism that is at the same time very old and fundamentally new. It is old because it appeals to relentless competition in the pursuit of profit, and individual satisfaction (deferred or immediate) is its driving engine. But it is fundamentally new because it is tooled by new information and communication technologies that are at the roots of new productivity sources, of new organizational forms, and of the formation of a global economy the profile of this new world we are living in is shared by all countries despite the diversity of their cultures and institutions (Castells 1999, p. 2).

Castells' economic analysis, as well as that of political economists, reminds us that for capitalism to continue functioning, it had to create ever-expanding markets and become global. As in the past, new technologies aid in this endeavor. However, his work also has a trace of technological determinism. Immigrant diversity and intercultural communication get celebrated along with the advances of Silicon Valley. Castells was aware that those benefiting the most from new technologies and labor systems were not immigrants assigned to low-skill jobs. Unfortunately, these nuances are lost in the many people who later cite Castells as talking about a trifecta of new technology, global migration, and economic restructuring as an unstoppable trinity.

Castells notes how the "extreme flexibility of the system" allows for more links and networks to connect "everything that is valuable according to dominant values and interests," but that this same network also inherently disconnects "everything that is not valuable, or becomes devalued. This simultaneous capacity to include and exclude people, territories and activities is based upon a capacity to network" (Castells 1999, p. II). The analogy of a network to society is a useful one (King 2020; Salganik 2018; Watts 2003), but society is much more complicated than ICT networks. Social network theory and relational analyses emphasize ties and connections, but these preceded and go beyond IT social network sites or cable, ethernet, or fiber optic communication networks (Tilly 2005).

For David Held and his co-authors, "globalization is a central driving force behind the rapid social, political and economic changes that are reshaping modern societies and the world order" (Held et al. 1999, p. 7). They equate globalization to a "force" and use an expansive definition of globalization to explain all contemporary social change.

Postmodern authors embraced the images brought up by globalization. Appadurai (1996) wrote in stimulating ways about global production chains and the social meaning of consumption, but also about ethereal ethnoscapes and ideoscapes. Some authors tried to rein in postmodern claims or tunnel through post-material claims with empirical data or analyses grounded in historical materialism. In The Condition of Postmodernity: An Enquiry into the Origins of Cultural Change, neo-Marxist geographer Harvey (1989) writes about the relationship between changes in cultural and economic production. 
He describes changes in modes of production going, in his view, from modernism grounded in assembly-line production Fordism and Keynesian economic policies, to postmodernism and its emphasis on "flexible accumulation," with disposable labor as a quick response to changing consumer demands, and the increasing dominance of international financial markets.

Paralleling David Harvey, some authors talk about globalization as the compression of space and time. Papastergiadis (2000) states that globalization has commonly been used since the 1980s to

represent the perception of the world as an interconnected whole and the consciousness that a growing number of issues can no longer be addressed purely at a local level. Globalization has been predominantly associated with the flexible and spatially extended forms of production, the rapid mobility of capital, information and goods, the denationalizing of capital, the deterritorialization of culture, the interpenetration of local communities by global media networks, and the dispersal of socio-economic power beyond the Euro-American axis ... In the age of globalization the process of exchange and flow, it appears, is conducted on a series of smooth circuits that link distant places into a single time frame (Papastergiadis 2000, p. 76).

In this rendition, globalization is the sum of a long list of disparate elements. In the popular imagination, the "smooth" movement across space/time becomes almost like a beta version of teletransportation in Star Trek or traveling in hyperspace as in Star Wars:

The use of new communicational technologies in international financial transactions have given rise to a hyperspace of 'fast capitalism' as the global flow of capital, energy, goods and people speeds up to accompany the proliferation of images, simulations and symbols. These bypass geographical and political boundaries; are beyond the constraints of space and time; and, in this, are post-historical' (Benyon and Dunkerley 2000, p. 33 discussing T.W. Luke and Jean Baudrillard).

Therefore, in some "postmodern" texts, real changes in communication technology and economic transactions suddenly take readers to imagine science fiction utopias. Thinking about other possibilities, including "alter-globalizations" can be useful theoretically. However, the most dangerous theorizing about globalization happened in economics and political life. In the process of popularizing the term, the nuances, complexities, critiques, and new progressive possibilities around this new way to organize the economy were lost. Instead, for proponents of neoliberal globalization and the general public, the descriptions of the changes seen by social theorists became predictions of an unstoppable future. Rather than describe globalization as a set of policy decisions useful to corporations in the global north or as a profitable process, as Levitt (1983) did, many turned to describe globalization as inevitable.

\section{Neoliberalism or Inevitable Force?}

The 1980s marked a departure from the international economic system established at Bretton Woods. As Strange (1986) describes, state power was used to render states less able to regulate and rein in the national and international financial systems, giving more control to banks and financial traders. The system changed from one averse to crises to one that Susan Strange called "casino capitalism," where private actors pocketed the earnings. However, in cases of massive losses, taxpayers in many countries would foot the bill to save the multinational financial system and would face austerity measures even when they did not engage in any reckless behavior. Producing socialism for corporations and capitalism for the poor (Blyth 2013; Strange 1986).

These changes, and those to come, were due in large part to what many call "neoliberalism." As political economists, economic sociologists, political scientists, and historians have aptly documented-along with fortuitous events, crises, and unintended consequences-libertarians, neoconservatives, ordoliberals, neoliberal economists, anti-Soviet groups, and economic elites came together looking to decrease the size of the welfare state in Western Europe, roll back the policies 
of the New Deal in the United States, and create international legal regimes that reduced tariff walls, and protected capital and private property (Babb 2001; Bockman and Eyal 2002; Davies 2017; Harvey 2005; Krippner 2012; Portes 1997; Strange 1986). Neoliberal economic theory, as espoused by Ludwig von Misses, Friedrich Hayek, Milton Friedman —and many others affiliated with the Mont Pèlerin Society, the Geneva School, or the Chicago School—served as an ideological basis for national and international policies that reduced state responsibility for social services and welfare provisions and increased the independence of capital and the world economy (Slobodian 2018).

Neoliberals hijacked the theoretical work on globalization to advance their previous goals of creating an independent world economy free of democratic and populist constraints. Globalization-speech then became a discursive tool to spread neoliberal policies around the world in the form of structural adjustments and opening economies to trade from the U.S. and England. Neoliberalism went from business interests to ideology to state policy, but this spread took decades of lobbying campaigning, and in the process, the content of this ideology changed. An ideology initially advocating for no borders to capital inputs, including labor, became one in favor of lifting barriers to trade but in controlling immigrants and in differentiating between higher and lower cultures. This can be seen in the changing point of view in the work of Hayek himself (Slobodian 2018).

Former U.S. President Ronald Reagan is credited as a "pivotal figure" in the mainstreaming of neoliberalism, with scholars arguing that "his ideology and policies fed, encouraged, and supported the drivers of globalization" (Johns 2015, p. 609). In a 1981 speech Reagan gave to the World Bank and the International Monetary Fund, he said that the aforementioned institutions:

have worked tirelessly to preserve the framework for international economic cooperation and to generate confidence and competition in the world economy. They have been inspired by the ideal of a far better world in which economic growth and development would spread to all parts of the globe... These institutions have reflected a shared vision of growth and development through political freedom and economic opportunity. A liberal and open trade and payment system would reconstruct a shattered world and lay the basis for prosperity to help avoid future conflicts. This vision has become reality for many of us. Let us pledge to continue working together to ensure that it becomes reality for all (Reagan 1981).

In another one of his speeches, Reagan spoke about:

the changing economic realities-in which products are increasingly information and can be transmitted around the world at the speed of light- these new economic realities dictate a world economy. Because of our experience with a continental economy, we are uniquely situated to lead the world into a new era of economic cooperation, to make this "city on a hill" that is America, a global city. The watchword of this new era will be freedom- free enterprise, free trade, freedom to travel, freedom of emigration. Freedom- the emancipation of peoples' creative energies around the world. That's the challenge that has opened up to us in the 1980s (Reagan 1988).

Reagan promoted these policies while in office, especially in the context of the Cold War. This free trade discourse was widely reproduced by officeholders in the U.S., the U.K., Chile, Mexico, and beyond. In the U.S., both Republicans and Democrats openly embraced neoliberal globalization. Former U.S. President Clinton spoke about globalization in a speech in Vietnam:

Today the United States and Vietnam open a new chapter in our relationship, at a time when people all across the world trade more, travel more, know more about and talk more with each other than ever before. Even as people take pride in their national independence, we know we are becoming more and more interdependent. The movement of people, money, and ideas across borders, frankly, breeds suspicion among many good people in every country. They are worried about globalization because of its unsettling and unpredictable consequences. Yet, globalization is not something we can hold off or turn off. It is the 
economic equivalent of a force of nature, like wind or water. We can harness wind to fill a sail. We can use water to generate energy. We can work hard to protect people and property from storms and floods. But there is no point in denying the existence of wind or water, or trying to make them go away. The same is true for globalization. We can work to maximize its benefits and minimize its risks, but we cannot ignore it, and it is not going away ... Nations that have opened their economies to the international trading system have grown at least twice as fast as nations with closed economies. Your next job may well depend upon foreign trade and investment (Clinton 2000).

Here, while encouraging Vietnam to open itself to trade with the U.S., Clinton reproduces the mantra that globalization is a natural force that cannot be fought against.

Another public figure who endorsed globalization and popularized the term was Tony Blair, the former United Kingdom Prime Minister. In a 1997 Leader's speech in Brighton, he spoke about his "vision for post-Empire Britain ... to make [the] country pivotal, a leader in the world ... [because the UK] at times [has] been absolutely critical to the survival of not just Europe but the world." He goes on to say:

We want a people's Europe: free trade, industrial strength, high levels of employment and social justice, democratic. Against that vision is the bureaucrat's Europe: the Europe of thwarting open trade, unnecessary rules and regulations, the Europe of the C.A.P. and the endless committees leading nowhere. But we cannot shape Europe unless we matter in Europe. I know there will be a hard choice to come over a single currency. And our policy, based on the British national interest, remains unchanged. But in or out, we will be affected by it and must remain able to influence the way it works (Blair 1997).

Blair, similarly to Clinton, references the concept of globalization, namely free trade, as an almost inevitable force. Blair says that since the United Kingdom will be affected by this force, the nation must be able to influence it, primarily to retain the state's own power and control. As apparent in this speech, national political and economic elites were not really thinking about globalization as a force for leveling the playing field, universalizing trade, and reducing global inequality. Instead, they wanted to create multi-state trade agreements that would benefit economic superpowers like the United States and Britain, with success to be determined in improvements in GDP and national wealth, rather than in increasing the overall wellbeing of the world's population. The decision of the United Kingdom then to stay in the European Union but not to adopt the Euro is an example of the options that large economies have in the tailoring of trade and monetary policies to fit their interests.

Nonetheless, after de-industrialization widely affected local industrial working classes in the United States and the United Kingdom, this pro-globalization discourse also opened the door for critiques of "globalization" and processes connected to it, such as immigration. This was something that many policy and business elites failed to imagine.

After the fall of the Berlin Wall in 1989, the demise of the USSR, and China's incremental opening to international trade, President Bill Clinton celebrated "The New Economy." The Internet brought with it the potential to connect people across national borders, allowing them to trade goods and ideas faster than ever before. The roaring 1990s saw campaigns around "Globalization," sold as an unstoppable and inevitable natural force. Thomas Friedman celebrated that people around the world were eating at McDonald's, drinking Pepsi, wearing jeans, and listening to Rock n' Roll (Friedman 1999). Capitalism had won the ideological battle (Fukuyama 1992).

Proponents of market solutions gained influence during the administrations of Bill Clinton and Tony Blair in the U.S. and the U.K., respectively. Insider accounts of Clinton's administration discuss the ideological struggles between factions favoring capital over those supporting workers (Reich 1997; Stiglitz 2003b). Rather than pitting conservatism and social democrats, Anthony Giddens advocated a move to the center, triangulation, or a "third way" (Giddens 1999; Giddens 2000). The New Democrats and New Labour gained electoral support. They spun the anti-tax goals of the wealthiest one percent 
that had been previously advanced by Reagan and Thatcher (Harvey 2005) into a new narrative that sounded tolerant and internationalist. The amalgamation of different trends of social change into the "globalization" umbrella brought together liberals, conservatives, and cosmopolitans. The Democratic and Labour parties gained electoral success then. Still, this strategy ultimately weakened them because now these parties are not seen as credible when they say that they advance the interests of the workers and the middle class, thus opening space to the populist right, as is discussed later in this paper.

In the late twentieth century, globalization became an "economic buzzword." Think tanks like the Cato Institute, Brookings, and the American Enterprise Institute, newspapers such as The Wall Street Journal, and magazines such as The Economist advanced the gospel of global free trade and reduced government intervention in economic affairs.

In a meta-review article, The Economist traced its use of the term globalization from 1979, around the start of neoliberalism until 2009, after the Great Recession (The Economist 2009). Similarly, the authors compared many articles in the magazine and found a shift in the meaning of "globalization." A piece from The Economist from the 1990s reads:

For good or ill, globalisation has become the economic buzz-word of the 1990s. National economies are undoubtedly becoming steadily more integrated as cross-border flows of trade, investment, and financial capital increase. Consumers are buying more foreign goods, a growing number of firms now operate across national borders, and savers are investing more than ever before in far-flung places (The Economist 1997).

In this context, a more globalized world would equate to a more "globally integrated economy." The Economist also argues that the surge of globalization in the 1990s was not something new, and that "The present surge of globalisation is in a way a resumption of that previous trend" (The Economist 1997). While The Economist clearly outlines globalization as an economic process, it is interesting to look at the discourse and events surrounding the word's usage in the article. For example, when it outlines that globalization was evident 50 years before World War I, it describes the state of Pre-World War I globalization as "large cross-border flows of goods, capital and people" (The Economist 1997). In this particular context, the flow of people is included in the portrayal of previous waves of globalization.

On a later date, in The Economist column Buttonwood's Notebook, John O'Sullivan discusses globalization in association with the free flow of capital, trade, and economic prosperity, in the form of higher GDP per capita. He claims again that as a result of the internet, the movement of ideas is cheaper and faster now, and that globalization has led to more efficient production in industries, making borders largely irrelevant to supply industries, and consequently, trade has become denationalized (O'Sullivan 2016b). However, later O'Sullivan talks about an “inevitable" backlash. He reiterates that globalization is mostly "about the more efficient allocation of resources- labour, capital, even land" (O'Sullivan 2017) but argues about the inevitability of a decrease in globalization like what happened in 1914 and the start of World War I. Therefore, the "inevitability" of globalization asserted by the proponents of economic globalization is now accompanied with the "inevitability" of a backlash. This makes sense in a dialectic framework, but it is a revisionist history and is equivalent to "having your cake and eating it too" for economic forecasters and prognosticators. Throughout The Economist's articles, there is an ideological continuity in how the publication defines and defends globalization, sporadically nudging to events in reality that dampen this globalist discourse, but that cannot be ignored: the 2008 Recession, the election of Trump, the border wall, Brexit, COVID19.

\section{Circular Thinking}

Economist Richard Baldwin argues that, "The contours of industrial competitiveness are now increasingly defined by the outlines of international production networks rather than the boundaries of nations" (Baldwin 2016, p. 6). Therefore, as a result of this "inevitable" process, the production and distribution of goods cannot be limited by national borders. A suggested way nations can respond 
to this development is by removing tariffs and join what is referred to as the "global value chain" (Baldwin 2016). Other scholars have also written about actions, such as the "removal of tariffs," in their discussion of globalization, and list as examples of globalization "the removal of tariffs and tariff barriers to trade, and capital account liberalization (the removal of restrictions on international investment flows)" (Weisbrot et al. 2001). They define globalization as "the increased opening to international trade and financial flows that has occurred in the vast majority of countries in the world" (Weisbrot et al. 2001). According to this definition, "globalization" is an economic model, one of increased free trade and economic interconnectedness.

The circular reasoning of these arguments should be noticed, where one simultaneously defines globalization as including the decrease in tariffs and recommends governments to do so. In other words, globalization has become justified by saying this is how things are, but in fact, you must change your policies to be how it is. Rather than being about the deregulation of the market, neoliberal policies require the reregulation of market relations (Bandelj 2009; Fligstein 2001; Vogel 1996). Neoliberal economics postulates that the markets are self-regulating and autonomous. Nevertheless, neoliberals engaged quite directly in politics and international institutions to create regulations that encased the economy and isolated it from popular politics (Slobodian 2018).

There is a contradiction in the logic that an inevitable global system can only fully materialize after coordinated policy changes worldwide occur. This circular logic escaped many enthusiasts at the time. Its teleological argument helped push for destructive and unpopular policies throughout the developed and developing world. Rather than describing a natural phenomenon, particular actors were, in fact, engineering a world to fit neoliberal theory (see MacKenzie et al. 2007 and the literature on the performativity of economics).

O'Sullivan, a columnist in The Economist, describes globalization as an "inevitable" process in which people should function. Still, in a twist contradicting years of advice from the magazine, O'Sullivan writes, "globalisation is an inevitability in a world of modern communications that cannot be uninvented. But it will not be possible to combine globalisation with a small-state approach" (O'Sullivan 2016a). Beyond the popular backlash against globalization, the crises of 2008 and the one created by COVID19, have demanded government intervention in regulating the economy, salvaging industries, protecting citizens, and providing some basic healthcare. Libertarians and pro-market economists can less successfully argue for a small state.

\section{Open Borders but Nor for People}

Globalization and neoliberal ideology did not end in the pages of The Economist. Reagan, Thatcher, Clinton, Blair, German Chancellor Gerhard Schröder, and many others, embraced open borders for their exports, capital, ex-pats, and transnational corporations but not necessarily for low-skilled labor immigrants. Despite the immigration amnesty provided by the Immigration Reform and Control Act (IRCA) signed reluctantly by Reagan in 1986, the legislation called for a crackdown on unauthorized immigration while still maintaining some regulated immigration. IRCA stated that employers could not knowingly hire undocumented immigrants, and if employers were caught, they would face a severe fine (Maddux 2005). As governor of California, Reagan in 1981 framed immigrants as competitors in the labor market:

By cracking down on those employers who knowingly engage in the hiring of illegal aliens, this legislation can help to improve job opportunities for thousands of legitimate California residents and is fully consistent with provisions of the state's new welfare reform law which limits welfare benefits to only those aliens who reside in California legally (Reagan 1981 cited in Maddux 2005, p. 204).

Clinton implemented stricter immigration legislation and stated, "We must not-will not-surrender our borders to those who wish to exploit our history of compassion and justice" (McAndrews 2015, p. 106). He signed legislation committing to stricter border control, toughened 
penalties for bringing undocumented immigrants across the border, or employing them, as well as denying Social Security and other benefits to immigrants (Van Hook and Bean 2009).

Even though the 1980s and the 1990s saw an increase in support for globalization, they also saw political and legal resistance towards immigrants. Politicians saw an interconnected world by expanding the domain of capital, but simultaneously opposed the opening borders to immigration (McAndrews 2015). Tellingly, the North American Free Trade Agreement between the United States, Mexico, and Canada (NAFTA) purposely did not include any discussion about the movement of people across the borders of these three countries (Castañeda 2007).

The last two decades of the twentieth century saw a rebirth in the belief in "free markets," the reduction of tariffs, deregulation, and an increase of international trade, as with the simplistic understanding of the liberal economic theory of the nineteenth century, which is why this policy agenda is called neo-liberalism. This was a celebration of the British Empire and its global reach, where many markets were open to international competition. By the late 1990s, this ideology gained such force and quasi-religious zealotry that many authors call the dogmatic belief in the power of free markets: "market fundamentalism" (Block and Somers 2014; Frank 2000; Stiglitz 2003b). Subscribers to the neo-liberal ideology asked governments to refrain from intervening with market forces. Industrial and financial capital was allowed to move freely through most national boundaries.

Why is it that, despite the rise of international discourse in favor of universal human rights, the liberalization of markets, and economic globalization in the last decades, there has not been a decrease in national identifications or an opening of borders besides within the European Union? Migrants serve a positive role in the labor force of their host economies, so why do they face such strong opposition in the broader public discourse? As discussed elsewhere (Castañeda 2019), economic and political liberalism approach migration and the nation-state differently.

Advocates of multilateralism and international law had a significant influence in policy circles in the 1990s. This decade saw a quick rise in international non-governmental organizations and the legitimization of multilateral institutions among cosmopolitan elites and middle classes. Nevertheless, despite all the speeches, advertisements, promises, and utopias about building a Global Village-where the concept of the nation-state would disappear-there are a few indications that the different nation-states are ready to give up their sense of autonomy and reified sovereignty (Feldman 2018). However, the nation-states still matter. Studies are incomplete if nationalism is not included in the analysis of inter-group relations between immigrants and established residents (Castañeda 2019; Jiménez 2017).

Nevertheless, some theorists were too quick to claim the decline of the importance of the nation-state and the convergence of humanity into one economic system and global culture. However, this claim is wrong. There are different varieties of capitalism with strong welfare states in Scandinavian countries and more laissez faire regimes in Latin America, as well as mixed systems, being very successful at developing in Asia (Hall and Soskice 2001). While global trade has increased in relation to the interwar and postwar periods, it was probably proportionately higher at the end of the nineteenth century than at the end of the twentieth (Chatterjee 2004, p. 84). Some goods and capital may move freely across the world, but migration has been deliberately controlled. Except for Europeans traveling within the European Union or the Schengen area (and beyond), most countries still have relatively closed borders. Despite outcries about migration and refugee crises, global migration is not higher than it was in the nineteenth century (Chatterjee 2004, p. 85).

A teleological approach that claims a natural, historical progression or evolution into a world without borders should not be assumed. Nor should a world organized in clearly delineated nation-states be taken as the only option for the future. Instead of taking for granted the right of a national government to dictate migration and population policies, these assumptions should be probed to understand why national identity and borders have kept their strength.

Throughout the 1990s, politicians and the media often conflated globalization with immigration, seeing them as inevitably linked or even synonymous. A Wall Street Journal article from 1991 talks about 
economic globalization and makes a case for bringing highly skilled workers from abroad. It describes how changes to immigration law "will make it easier for U.S. companies to draw talent from other nations, mostly by tripling to about 140,000 the immigrant visas allotted to managers, professionals and others with skills in demand here. And by improving the U.S. work pool, it eventually should enhance corporate America's competitiveness world-wide, proponents say." It then quotes, "Economist Stephen Moore of the Cato Institute, a Washington think tank, concurs: "The globalization of the economy has just begun. The demand for this type of (foreign-transfer) visa will just explode in the next 20 years'" (Valeriano and Lublin 1991). Legal skilled migration did increase, but so did undocumented migration. However, in terms of relative magnitude, capital flows across borders and global production chains dwarf migration flows.

\section{Migration Wrongly Subsumed under Globalization in Social Theory}

Social science and humanities publications on immigration often include in their titles or introductions phrases such as in this "the age of migration," "the era of mass migration," "the migration crisis," and they often claim that globalization has led to increased migration. In their arguments, some authors present international migration as both a cause and effect of globalization. For others, immigration is a crucial element of globalization. Papastergiadis (2000) refers to globalization and migration as "twin processes." He argues that globalization and migration have altered the standard notions of borders and national identities (Papastergiadis 2000). However, neither migration nor long-distance trade are new. Colin Crouch writes that, "Increased trade has also brought strengthening relations of all kinds across much of the world; thus the other side of the coin of cultural challenge represented by immigration (sic)" (Crouch 2019, p. 43). Nonetheless, trade does not necessarily entail mass migrations. The opposite is also true, to cite an extreme example, there is little legal trade between the United States and Cuba, but there has been significant migration from Cuba to the United States. The same could be said about refugees from behind the iron curtain or about people going to Israel from around the world whether those countries have trade agreements with Israel or not. People migrate for political, religious, and economic reasons that have nothing to do with multilateral trade or foreign direct investment (FDI).

It is not uncommon for academic books, articles, and reviews to start with phrases such as this, "Contemporary global migration, probably one of the most visible faces of globalization, has stimulated an interesting and broad theoretical discussion in both academic and political circles" (Hatziprokopiou 2002, p. 429). There have indeed been many theoretical debates about migration and its connection to globalization. Nonetheless, relatively little empirical work has been conducted to test the hypothesis that international migration is "a face of globalization." Migration is included in many definitions of globalization, but its inclusion may be analytically misleading:

There is growing acknowledgment among scholars and public policy practitioners that globalization is associated with the increasing scale and scope of international migration ... [Yet] The limited scope of previous analyses has left fundamental questions about international migration unanswered: How does globalization influence the prevalence of international migration? (Sanderson and Kentor 2009, pp. 302-3).

A few studies have looked empirically at the claims about an increase of migration caused by globalization. The conclusions point to the role of FDI and development in general in producing urban to rural migration, which often turns into international emigration. Nonetheless, this is not new to globalization (Heyman 2018). Though, the widespread concept of immigrant illegality is a relatively new concept that was absent from previous waves of globalization (Donato and Massey 2016). In the United States, the Chinese Exclusion Act and previous racist and immigrant restrictionism kept some groups at bay (Camacho-Beltrán 2019; Castañeda 2019; Ngai 2004). Nonetheless, the coexistence of a population that is both unsanctioned and active in the labor force without safeguards and vulnerable 
to deportation is a new development that goes beyond the United States (Castañeda and Beck 2018; Golash-Boza 2015; Koopmans 2009; Rung 2020).

Vertovec (2007) coined the term "super-diversity" to talk about an increase in immigration from a larger array of countries into Britain. Nevertheless, globalization has not increased the number of countries of emigration, and in the last decades, the places of destination have actually decreased.

the total volume of international migration has not increased in relative terms, whereas migrants tend to concentrate in a shrinking number of prime destination countries. Also, while the number of empty migration corridors has decreased, migration has tended to concentrate in the larger corridors. This seems to contradict some key hypotheses of the globalization of the migration paradigm (Czaika and Haas 2015, p. 316).

Therefore, not only are migration flows less diverse in terms of destination, the overall percentage of the world population on the move remains rather stable, at between 2 and $3.5 \%$ of the total world population (Czaika and Haas 2015, p. 287, Donato and Massey 2016, p. 7, Sanderson and Kentor 2009, p. 301, Zlotnik 1999, p. 42). During the 1870-1914 period, migration rates were much higher than they are currently (O'Sullivan 2017). To say that immigration is larger than ever in terms of raw numbers is nonsensical because the world population is continuously expanding. Furthermore, how the concepts of diversity and super-diversity have been implemented in the business sector and policy world are problematic (see Doytcheva 2020).

Often, the cultural diversity brought about by migration is celebrated and justified in works that study immigrant and transnational communities. This does not mean that every globalization advocate also calls for open borders for people. According to Papastergiadis, globalization exposes nation-states' limitations, and by doing so, undermines their autonomy. He also writes about how an increase in globalization brings about a willingness to implement harsher migration controls:

Every nation-state is at once seeking to maximize the opportunities from transnational corporations, and yet closing its doors to the forms of migration that these economic shifts stimulate ... As nation-states are losing more and more of their power to regulate activities within their territory, they are becoming increasingly aggressive about the defense of their borders. Tougher laws against asylum-seekers, the rounding up of gypsies (sic) and ruthless eviction of 'economic migrants' are some of the ways in which governments vent their frustration in a world where they have seemingly lost control but dare not admit it (Papastergiadis 2000, pp. 2-3).

Despite evidence of the limits of human mobility, Papastergiadis still connects migration to globalization. Analogies of turbulence, chaos, fluidity, hybridity can be taken too far, "As compelling as they are, the images in this book cast an inaccurate picture" (Fernández-Kelly 2001).

In scholarly works, migration is brought up as a "societal impact" of increased globalization. Other scholars refute the claim that migration is a byproduct of globalization, and instead argue that migration as a process has been occurring even before the current phase of globalization. Saskia Sassen argues that the inclusion of migration into globalization entails

engaging a vast scholarship that is not particularly focused on globalization ... It entails contesting a very different type of scholarship, as yet minor but growing fast, that seems to assume that we have immigrants because of globalization, an assumption it arrives at not through knowledge about migrations but by projecting standard globalization notions onto migration (Sassen 2007, p. 129).

There are indeed some new aspects of mass immigration:

Today the sharp growth in the organized export of workers, both legal and illegal, adds another dynamic to the older, long standing ones. Organized exports can create whole new ways of linking emigration and immigration countries, beyond old colonial or new global economic 
links. Yet these new developments are also often linked to broader contextual conditions (Sassen 2007, p. 133).

As Sassen explains, globalization is not the leading cause of migration. Still, the new global socio-economic context adds another dimension of understanding how migration operates today and how international foreign investment affects it.

Overbeek makes a similar argument: that in order to gain a better understanding of the "refugee crisis" of the 1990s in Europe, one must look at the economic context, particularly the reorganization of the global economy in the 1970s. He defines globalization as "a process of structural transformation of the global political economy, historically unparalleled and with tremendous impact on the lives of billions of people. This transformation takes place in the sphere of both production and finance, and has far-reaching repercussions for the role of the state" (Overbeek 1995, p. 22).

Many link immigration and globalization. However, there is little empirical evidence actually linking the two. Sassen's earlier work (Sassen 1988) indeed shows a relationship between foreign investment and the increase in migrant labor. Maquila work-sweatshops and micromanaged factories often employing women in special development zones in developing countries (Fernández-Kelly 1983; Salzinger 2003; Young 2015) —and export-led development did produce some economic development. By disrupting local socio-economic systems (Sassen 1988), they also caused higher outmigration, internal migration from southern Mexico to border towns, and also to the United States.

Another evident example is the opening of the Mexican market to corn manufactured by large and state-supported agro-business in the United States following NAFTA. This made many small farmers, especially indigenous farmers with smallholdings in the center and south of Mexico, vulnerable to decreasing prices, making it harder for them to support themselves with their land. For a while, this made internal and international migration some of the few avenues for the farmers to support themselves after their agricultural production became untenable beyond self-subsistence (Gálvez 2018; Garip 2017; Jones 2014).

Many countries have intermittently become increasingly selective about immigrant acceptance, open to highly-educated, skilled, and wealthy immigrants (Czaika and Haas 2015; Harpaz 2019), while relatively restrictive in relation to non-white working-class individuals (FitzGerald and Cook-Martín 2014; Zolberg 2006). Countries then marginalize and exploit undocumented and temporary migrants (Castañeda 2019; Donato and Massey 2016; Rung 2020).

Many argue that remittances - the money that immigrants send to their family members in their home country-are evidence of "globalization from below." There is a whole discourse framing remittances as "a development tool." This talk is full of neoliberal assumptions and is detached from grounded evidence. The policy discourse on remittances is so widespread that this is discussed in detail elsewhere (Bakker 2015; Castañeda 2013; Castañeda n.d.; Hernandez and Coutin 2006).

\section{Cultural Globalization}

Many fear migrants and guest workers because they bring not only their labor force but also their families and culture. Along with claims about the effects of globalization, some talked about the creation of a global culture, e.g., "in terms of sociocultural relations, globalization involves the migration of people and customs" (Laws 1997, p. 91). Another part of the discourse surrounding globalization is that it threatens national cultures. However, for some, globalization merely presents "new cultural symbols and practices through which individuals will understand their position in the world ... the new manifestation [of culture] should not be confused with the death of culture" (Papastergiadis 2000). Several scholars discuss globalization in conjunction with identity politics, multiculturalism, and citizenship. Castles and Davidson (2000) use the term "globalization" almost interchangeably with "cultural diversity," writing that 
Globalization, the increased mobility of people and the burgeoning of new forms of communication make myths of homogeneity unsustainable. Cultural diversity has become a central aspect of virtually all modern societies (Castles and Davidson 2000, p. 127).

They also talk about challenges faced by minorities, such as social exclusion despite legal citizenship, and a wavering sense of belonging. However, these realities can be explained without having to attribute them to globalization (Castañeda 2018c). National myths of homogeneity are indeed empirically unsustainable, but as shown in their own book, diversity and multicultural cohabitation were true of Rome and its Empire, as well as the British Empire and most political bodies in history. War is the number one determinant of national borders rather than bloodlines or common language (Castañeda and Schneider 2017; Crouch 2019, p. 58).

Whether it is spoken about as a catalyst for cultural unity or cultural division, globalization is at the forefront of the contestation of the prospective evolution of culture. In Global Culture: Nationalism, Globalization and Modernity, British sociologist Mike Featherstone discusses a "globalization process which points to the extension of global cultural interrelatedness" (Featherstone 1990, p. 6). He makes the ambivalent arguments that cultural exchanges lead to "transnational cultures" and "cultural homogeneity and cultural disorder" (Featherstone 1990, p. 6). Robertson goes further as he defines globalization as "the crystallization of the entire world as a single place" (Robertson 1987a, p. 38) and as the emergence of a "global-human condition" (Robertson 1987b, p. 23). These are overstatements that are difficult to document across the world. Sociologist Zygmunt Bauman outlines how globalization is paradoxical, in the sense that it

divides as it unites-the causes of division being identical with those which promote the uniformity of the globe. Alongside the emerging planetary dimensions of business, finance, trade and information flow, a 'localizing', space-fixing process is set in motion. Between them, the two closely interconnected processes sharply differentiate the existential conditions of whole populations and of various segments of each one of the populations. What appears as globalization for some means localization for others; signaling a new freedom for some, upon many others it descends as an uninvited and cruel fate (Bauman 2010, p. 1).

Bauman depicts globalization as an uncontrollable, disorderly power, and argues that in the "deepest meaning" globalization portrays the existence of an anarchical system, void of a centralized power to control global affairs. These are other examples of the overtheorizing around "globalization" among some social theorists. The authors of this paper argue, originally, that these claims opened the door to many criticisms of globalization—some based on fact and others on myth as is discussed below.

\section{Early Critiques}

Critiques of economic globalization from the political right are relatively recent. On the other hand, the left had much earlier critiques and more sophisticated analysis, although some critiques also confounded globalization and immigration. For example, an article from 1992 does raise awareness about the inequalities that developing countries faced with international growth taking place, specifying the mechanisms connecting globalization and emigration. The author argues that because globalization leads to unequal development, it, in turn, leads to larger emigration from the Global South (Klare 1992). Others have shown how foreign direct investment (FDI) and local development produce emigration (Sanderson and Kentor 2009; Sassen 1988; van der Waal 2013). However, FDI is not going to every place in the world. Instead, there is a very concentrated set of financial flows. Furthermore, FDI existed before the 1980s.

The neoZapatistas (EZLN) in Chiapas, Mexico were early critiques of neoliberal free trade agreements, taking arms on 1 January 1994, the same day that NAFTA was going into effect. They inspired "anti-globalization" or more aptly anti-neoliberal globalization and "alter-globalization" protests against the World Trade Organization (WTO) in their meetings in Seattle in 1999 and the G8 meeting in Genoa in 2001 (Della Porta 2006; Wood 2008; Wood 2012). These protesters were 
not anti-immigrant, they were against the advantages that large corporations were gaining through international trade agreements.

The critics of neoliberal globalization were skeptical about the inflated claims about global economic development to be produced by these policies. They predicted that the expansion of these policies would increase inequality between rich and poor countries and also increase inequality within countries and favor the rich (Della Porta 2006; Easterly 2006; Rodrik 1997; Rodrik 2007; Sassen 1998; Stiglitz 2003a; Tilly 1995).

One of the most significant counter-arguments for market fundamentalism is that globalization became, to a large degree, about American companies manufacturing their products in China (Karabell 2009). The main increases in development and poverty alleviation have happened in Asia, but particularly in countries that rejected the Washington Consensus and whose governments played an active role in supporting specific industries and setting their own terms for engaging with international markets (Stiglitz 2003a). The role of centralized economies in the world economy is at once a rejection of "globalization's" abstract conceptualization, an integral part of the empirical reality, and a testament to the degree of international interdependence.

\section{The Declining Public Interest in Globalization}

The Economist (2009) notes that the 2008 recession led to a decrease in the use of the term globalization. As Figure 2 below shows (The Economist 2009), articles about globalization grew in the 1980s and 1990s and decreased after 9/11. They increased again and then dropped with the Great Recession of 2008.

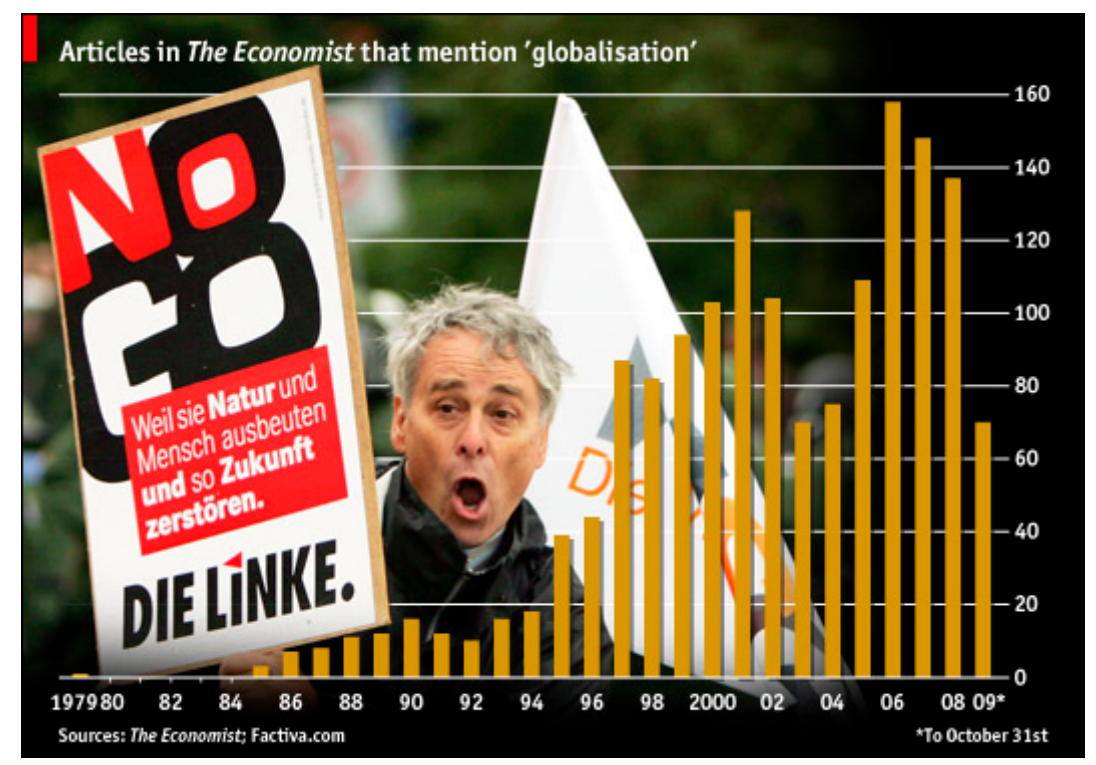

Figure 2. Articles published in The Economist using the word "globalisation" until October 31, 2009. Source: The Economist, 2009. Used for non-commercial purposes under fair use.

According to Google Trends (2020), since January 1, 2004—the earliest date where the information is currently publicly available - the interest in "globalization" as a web search has steadily decreased over time. By November 2017, the search frequency was approximately a quarter of that from March 2004 (yellow line in Figure 3 below). This decrease could be because the term became less "fashionable" or because people had become familiar with the term. The variance of "globalisation" as spelled in the United Kingdom and other countries also follows this trend.

As can be seen in Figure 3, internet searches for "migration" (yellow line) follow a very different pattern from "globalization" (green line). The searches for "migration" are the most common, and they are much higher for "immigration." They decreased in 2010 and 2013 and increased again later. In the 
graph below, the blue line represents the search interest on "inequality," which is nearly a mirror image of the search interest in "globalization." While in 2004, searches for globalization were higher than those for inequality in 2013, the interest in inequality is much higher than that in globalization. In a way, popular interest in globalization may have been replaced by a preoccupation with the growing inequality. As a comparison, the search trends for climate change were included, which have increased lately. This chart does not denote any factual correlation. It just denotes trends in what terms people within the United States googled from January 2004 to March 31, 2020 (Google Trends 2020).

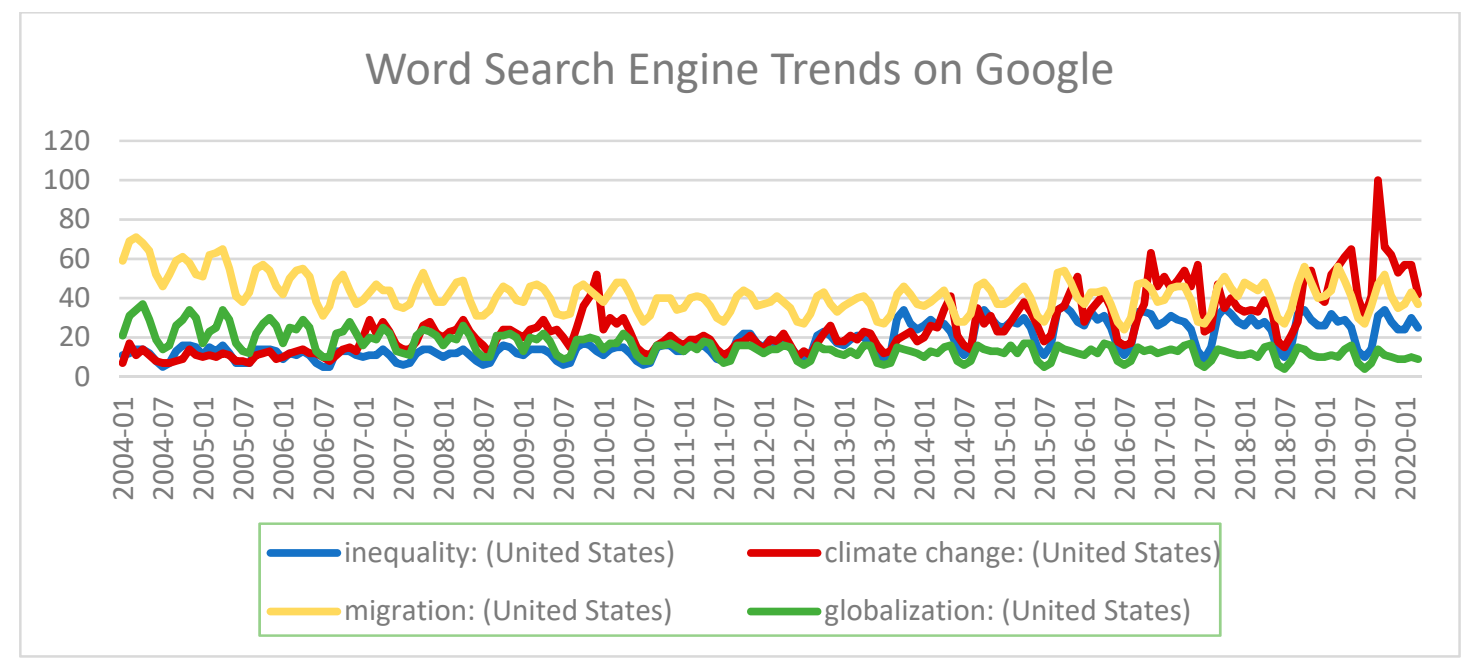

Figure 3. Google Search Trends.

\section{Opposition to Globalization from the Populist Right}

In a 2008 article from The Economist, the definition of globalization is retraced, arguing that globalization has changed from once meaning that businesses "expanded from developed to emerging economies" to one flowing in both directions "and increasingly also from one developing economy to another" (The Economist 2008). Globalization, in this context, is associated with fast changes in industries and sectors. Free markets and open borders to trade became an ideological, unquestioned, positive, and hegemonic in relation to capital, but many neoliberals question their application to people moving freely.

Another effect of globalization is that as the market becomes more integrated, "communities from disparate parts of the world" are brought together, particularly around labor, expanding trading networks to "include wider specialisations" (R. 2013). When seen as an economic process involving free trade and open borders, "globalization" can be met with skepticism from the public-mainly because of globalization's association with "foreigners" and the public's fear of job outsourcing:

More than six out of ten [Americans] are skeptical of free trade. A new poll in Foreign Affairs suggests that almost nine out of ten worry about their jobs going offshore. Congressmen reflect their concerns. Though the economy grows, many have become vociferous protectionists ... More likely, the structural changes in America's job market that began in the 1990s are now being reinforced by big changes in the global economy. The integration of China's low-skilled millions and the increased offshoring of services to India and other countries has expanded the global supply of workers. This has reduced the relative price of labour and raised the returns to capital. That reinforces the income concentration at the top, since most stocks and shares are held by richer people. More important, globalisation may further fracture the traditional link between skills and wages (The Economist 2006).

It took the Great Recession, Brexit, and the election of Donald Trump for some to take these drawbacks seriously. In contrast, Trump began talking about trade deficits since the late 1980s, even 
before people widely used the term globalization. He went on talk shows, including Oprah, and blamed East Asia for stealing industries from the U.S. (McKevitt 2018). Many years later, the fight against free trade to protect the jobs in the United States was a large part of his presidential campaign. Trump began to discredit the Trans-Pacific Partnership and promote the employment of workers in the U.S. against the claims about the plentiful benefits of international trade (Brands 2018). Trump claimed to support the individuals within the United States who have suffered the most from globalization. For example, he tweeted, "Remember, NAFTA was one of the WORST Trade Deals ever made. The U.S. lost thousands of businesses and millions of jobs. We were far better off before NAFTA—should never have been signed" (Bowden 2018). His campaign promised to protect white working-class Americans from the corporate elite. He stated in his Republican Convention speech:

I have visited the laid-off factory workers, and the communities crushed by our horrible and unfair trade deals. These are the forgotten men and women of our country. And they are forgotten. But they're not going to be forgotten long. These are people who work hard but no longer have a voice. I am your voice (Trump 2016a).

Despite branding himself for decades as a millionaire and a socialite, he suddenly took up the mantle of the national working class with some success. Many of Trump's supporters felt isolated and unheard, but he promised to bring back manufacturing jobs for Americans (Sawhill 2018). Trump was combining the critiques from the left about the adverse effects of corporate globalization on workers, along with racist attacks against immigrants, and people of color, and against foreigners, and Jews, who he framed as the same people profiting from economic globalization. He used the term "globalist," a term frequently used by the alt-right in anti-Semitic conspiracy theories (Castañeda 2019, p. 97).

\section{Trump and Economic Globalization}

Given these realities, much of the left has consistently shown opposition to economic globalization in the way it had been designed. The 1999 Seattle and 2001 Genoa protests were in opposition to a World Trade Organization summit and G8 summit, respectively; both were demonstrations against neoliberal globalization and not against immigration (Della Porta 2006). However, these protests were seen as radical, fringe, or "anti-systemic" by mainstream media. Later on, the Indignados and Occupy Walls Street movements protested the negative effects of neoliberalism, austerity measures, growing inequality, and the little wiggle room that even center-left governments had to fix issues or rein in financial speculation and debt (Castañeda 2012, 2015; Tilly et al. 2020).

Trump highlighted the disparity between global trade and wealth for the average American in a speech, "Globalization has made the financial elite who donate to politicians very, very wealthy ... but it has left millions of our workers with nothing but poverty and heartache" (Trump 2016b). Even though many still see globalization as a means to prosperity, Trump reached out to the people who saw globalization as the opposite. Many people have expressed their concerns about globalization on social media.

Globalization has increased the wealth inequalities between the $1 \%$ and the $99 \%$. A survey by the Pew Research Center from 2015 found that resentment towards free trade was at approximately $32 \%$ among Republican voters; however, its unpopularity increased to 63\% by the end of 2016. Approximately $30 \%$ of respondents in the U.S. had a negative perspective on free trade in 2015, which increased to 43\% in 2016 (Jones 2018). In 2016, approximately 47\% of Republicans stated that free trade hurts their community (Blendon et al. 2017). In a 2016 Bloomberg poll, 82\% of Americans said they would be willing to pay more for domestically produced goods, and two-thirds of Americans believe there should be restrictions on imported goods to protect American jobs (Ehrenfreund 2016). The sharp increase in frustration illustrates that as Trump grew in popularity in 2016, he either persuaded many Americans to view economic globalization negatively, or that-more likely-he captured the discontent with neoliberalism, underemployment, and underpay (Blendon et al. 2017) in a similar manner that Senator Bernie Sanders did in his primary campaign. 
In 2012, approximately 54\% of Americans believed that free trade creates job losses (Aguila et al. 2012). In 2018, 58\% of Republicans believed in raising tariffs on steel and aluminum (Jones 2018). Many want to increase protectionist policies because of globalization's harmful impacts on some industries and workers. Trump's rhetoric on globalization has itself caused a negative perception of globalization by dividing the American public on free trade while additionally changing the Republican Party's stances on free trade.

Trump has further influenced the perception of immigrants through his platform. He has continually pushed to expand border fences and walls between Mexico and the U.S. Many fear that immigrants and international trade take away resources from them (Hochschild 2016). Trump stated, "Mexico is making a fortune on NAFTA ... They have very strong border laws-ours are pathetic. With all of the money they make from the U.S., hopefully they will stop people from coming through their country and into ours, at least until Congress changes our immigration laws!" (Trump 2018). This tweet establishes another conflation, Trump mentions NAFTA, a free trade agreement, and border laws and migration in the same tweet, where he directs his anger towards Mexico because of trade and immigration. Even though he is increasingly referring to immigrants from other countries moving through Mexico, Trump blames Mexico for these immigrants coming into the country, whether they are immigrants actually from Mexico or Latin American immigrants. Studies indicate that prejudice against Mexicans is higher than that against other immigrant groups (Castañeda 2019; Flores and Schachter 2018; Short and Magaña 2002). Many wrongly believe that the border region next to Mexico is dangerous (Castañeda and Chiappetta 2020). Much of the prejudice has to do with economic frustrations, and resentment towards Mexico because of NAFTA and U.S. deindustrialization. Fifty-three percent of Republicans believed that Mexico benefits from NAFTA more than the U.S.A. does (Jones 2018).

As President, Trump continued to voice his dissatisfaction with Mexico, stating, "Mexico does nothing for us, they do nothing for us. Mexico talks, but they do nothing for us, especially at the border ... Certainly don't help us much on trade" (Korte and Gomez 2018). He states that Mexico does "nothing" for the United States. By mentioning immigration and trade in the same speech, Trump has connected economic globalization and migration by toxically conflating the two issues, which in the minds of most, were already entangled. Trump claims to protect white working-class' jobs from outsourcing to Mexico and from Mexican immigrants. Nevertheless, the two economies are deeply integrated; in fact, Mexico is the United States' third largest trade partner, following China and Canada (Felab-Brown 2017).

\section{Discussion}

Large changes in the labor market have been taking place since the late 1970s, with ever-increasing automation and routinization-producing the Luddite responses we have seen since the Industrial Revolution-and creating more precarious and insecure jobs (Kalleberg 2011). Labor unions started losing members in the United States, resulting in decreasing benefits and labor conditions. The new economy is reducing the income and respect afforded to blue-collar workers but also white-collar professionals (Sennett and Cobb 1993; Sennett 1998; Sennett 2003; Sennett 2006). However, this was produced intentionally by the neoliberal race to the bottom where only by reducing labor costs and taxation could companies compete internationally (Slobodian 2018, p. 43). Sassen (2001) writes persuasively about how globalization puts the interests of certain cities over those of the nation-state, and how these global cities that house the hubs that control the world economy have an hour-glass economy with a disappearing middle class.

Neoliberalism is not new, and its adverse effects in terms of labor markets and inequality have been documented by many. Trade agreements not only remove walls to commerce but also engineer new social and power relations (Chorev 2007; Duina 2006). New work is documenting the impacts of the world economy on the environment and climate change. In his recent book The Globalization Backlash, Colin Crouch writes, 
This might have happened under any economic regime, but the dominance of neoliberal policies made it difficult for governments in poor countries to protect their economics from fitting in with whatever fate participation in global markets assigned to them. Forests and other natural environments have been destroyed, ecological balance disturbed, and disease spread across the world, as governments have searched to engage their countries in the global economy, and as elites have sought to share in the rich pickings that such engagement brings. Global neoliberal hegemony allowed them to do this without taking social and environmental costs into consideration (Crouch 2019, pp. 42-43)

As Crouch writes, the environment has been another victim of neoliberalism-and industrialization and capitalism in general. Crouch advances an argument parallel to the first part of the argument in this paper,

If concern at the disruption to life caused by neoliberalism can be channeled into blaming ethnic minorities and other potentially unpopular groups, strengthening the increasing xenophobia of conservatism, then neoliberals can be left in peace to intensify a globalizing insecurity that will then be blamed further on the minorities, reinforcing even further the appeal of their incongruous conservative allies (Crouch 2019, p. 9)

This helps explain Brexit, Trump, and many other rightwing electoral successes. However, while useful in the short term, xenophobia itself cannot improve real standards of living and health outcomes. Democratic governments cannot go as far in their attack of minorities as white nationalists would want. Fascism creates its own resistance and cannot last forever. A backlash to the backlash is bound to occur. Nonetheless there is no need for dedemocratization to occur before foreign-born residents are included in local governance.

In his book, Crouch also equates globalization with migration, and sees the latter as somewhat challenging and problematic, and he holds on dearly to the virtues of globalization. Crouch is wrong when he writes that, "Globalization is a major cause of migration; hostility to immigrants is currently threatening the viability of globalization" (Crouch 2019, p. 38). Hostility to immigrants is "threatening" in itself. Fair trade does not have to accompany xenophobia and claims of cultural superiority. Furthermore, this argument is faulty. Migration and ethnic diversity would not go down drastically if tariffs on exports were to increase or if trade agreements were to end, largely because there migration preceded the 1980s.

It neither follows that ethnic diversity leads to a weakening of popular support for the welfare state (Crouch 2019, p. 8). There may appear to be observational correlations of these trends. However, the cause of a weakening of welfare states is more likely to be neoliberalist policies that lower taxes for businesses and, therefore, produce fewer funds to support the welfare state. Stereotypes propagated by neoliberals and conservatives that immigrants abuse the welfare state are but justifications for policy choices that they had already decided to implement.

\section{Conclusions}

The fact that so many people around the world-who came to favor free trade, individual responsibility, and entrepreneurship (Fridman 2017)—have now turned against free trade agreements is nontrivial. The explanation points to the inequalities exacerbated by the global expansion of neoliberalism. Social groups who lost their livelihood to profit-driven "outsourcing" and other economic changes now mistakenly blame immigration for their plight. No close research or analysis of the working-class' reactions was done here beyond citing opinion polls and secondary sources. However, much of this backlash is orchestrated at the political level by educated elites, some in the left but mainly in the right. For example, Boris Johnson is an expert orator and debater who uses the arguments of his opponents against them for personal gain. During the Brexit campaign, consultants were able to use popular fears and economic struggles to advance particular political agendas (Oliver 2016; Shipman 2016). Public anger is used instrumentally, and the working class is given false promises. 
For example, the desire of the Brexit voters "to take back control" as was the slogan of the Leave campaign, "is being interpreted by its main champions as an opportunity to weaken labour rights and food hygiene laws" (Crouch 2019, p. 10).

The argument of this paper is that social theory in the last decades created a logical opening for a backlash against globalization in the way it conflates-wrongly, in our view-economic globalization and immigration. A non-exhaustive set of passages from social theorists and policymakers was used to prove this claim. The conflation of globalization and migration is so hegemonic (or doxic) that to call it into question causes quick discomfort for some.

The career of the concept of "globalization" is an example of how some ivory tower conversations can have significant impacts in the real world, justifying political projects that academics cannot control. In the 1980s, 1990s, and 2000s, most authors wrote about globalization, migration, and long-distance connections in a positive, celebratory manner. However, a few fore-sought the way in which politicians around the world would use the negative effects of neoliberalism to support xenophobic, nationalistic, and authoritarian governments around the world.

Migration - the movement of people across space-preceded all waves of globalization. International migration, migration across the borders of political units, will continue even in a future period of deglobalization (with a smaller proportion of goods and services coming from great distances). Neoliberal economic policies are not the only causes of migration, but neither is global trade the cause of peaceful dialogue among people born in different parts of the world. Cosmopolitanism-having a global outlook and feeling like a citizen of the world-preceded Reaganomics. Immigrant communities clustered abroad engaged in transnational practices before globalization, the EU, NAFTA, or the spread of the internet (Castañeda 2017). Many of the migration pathways were established by former colonial enterprises and war rather than by the increase in international trade by itself.

Globalization is an example of a theory from the global north that spread around the world framed as a universal phenomenon. It had negative consequences for the working and middle classes in many countries and areas. These consequences and its connection to migration and elite cosmopolitan tastes helped create the allure of Donald Trump and Brexit. Many have written about the rise in xenophobia and right-wing extremism (Castañeda 2019; Miller-Idriss 2017), while others have raised the alarm about equally lopsided economic policies (Sassen 1998; Stiglitz 2003a). There is an ample amount of great empirical work on migration. Social movements have fought against neoliberalism for decades (Della Porta and Tarrow 2005; Della Porta 2006; Tilly et al. 2020). However, the general public is often not clear about what globalization actually is and what its real effects are. This paper brings together separate academic works from a number of disciplines and subject areas to make sense of the electoral developments at the end of the 2010s.

The term "globalization" is frequently used as encompassing, or even causing, international migration. However, it is important to keep three points in mind: (1) The term was first defined and discussed in a narrow business sense (Levitt 1983). (2) Globalization itself has not made significant changes to migration flows. (3) The expansion of capitalism has always demanded population movement from the countryside to new areas of production, e.g., cities (Castañeda 2018b; Sassen 1988).

Much of the conflation between globalization and immigration is exaggerated and misplaced. Nevertheless, the neoliberal economic policies associated with globalization-which have increased inequality and deindustrialization in the Global North - in the minds of many are associated with an increase in international migration. Therefore, it would seem that a justified way to protest deindustrialization, the precarization of labor, and growing inequality is to oppose or even blame international migration.

The linking of economic globalization and multiculturalism that has been perpetuated by many social theorists, pundits, mainstream media, and elites has helped fuel xenophobic nationalism and enacted the physical and social borders that are increasingly experienced. Therefore, it is also the duty of journalists, social theorists, and public intellectuals to set the record straight. Increasing wealth inequality and economic and public health crises should serve as an excellent reason for the return 
of widespread support for social programs and democratic practices that could be linked to place of residence rather than to place of birth (Crouch 2019; Raithelhuber et al. 2018). Citizenship and its benefits, along with empathy and solidarity, do not need to be tied to national citizenship or an assumed cultural homogeneity. In any case, migration should not be used as a valid justification to reduce social programs or people's rights.

The conflation of globalization and migration is factually wrong and politically dangerous because it has been used unethically to exploit xenophobia and economic anxiety for the benefit of opportunistic politicians. Economic policy-making should become open to democratic politics and processes, along with accurate information for voters (Baiocchi 2016; Castañeda 2014). The responses to the COVID19 pandemic show how economic policies that appeared impossible or undesirable before are indeed possible. The pandemic also shows how helping individuals in dire need is beneficial for all. A new world that includes policies that favor people over profits, and borders that are genuinely open and humane, is possible and within reach if people organize and advocate for it.

Author Contributions: E.C. conceived the argument while following the initial discussions around Brexit. A.S. produced the first draft including the initial quote selection as part of a seminar paper. E.C. rewrote the paper, contextualized quotes, and added relevant material and meta-theoretical discussions. E.C. prepared the document for submission and responded to readers'and reviewers' feedback. All authors have read and agreed to the published version of the manuscript.

Funding: No direct funding provided for the paper.

Acknowledgments: Ernesto Castañeda thanks Joseph Stiglitz and all the members of NSF's IGERT Globalization and International Development Program at Columbia University with whom he discussed what globalization is and what it is not, from 2003 to 2010. Castañeda thanks the theorists, economic sociologists, and network analysts in Columbia's Department of Sociology. He thanks the students in his "Borders, Migration, and Globalization" freshman seminar at American University in the fall semesters of 2017, 2018, and 2019 particularly for their pushback and their passionate defense of "globalization." Amber Shemesh was a student in the 2017 seminar and a peer leader in the 2018 seminar. Castañeda and Shemesh thank Cindy Van Dam, Bradly Knight, Sarah Marsh, Charles Cox, Richard Duncan, and the rest of the CORE, Complex Problems, and University College staff at American University for their support. Thanks to Gay Young for her general support. Sahiba Madan, Maura Fennelly, and Claire Whitman provided research and editorial assistance. Lesley Buck, Casey Chiappetta, and Daniel Jenks provided editorial feedback. Castañeda and Shemesh thank the efficient staff at Social Sciences, the anonymous reviewers for their recommendations and critiques, as well as Vida Bajc, Ho-Fung Hung, and the audience at the Eastern Sociological Society 2018 mini-conference on Globalization. All conclusions and errors are the sole responsibility of Castañeda.

Conflicts of Interest: The authors declare no conflict of interest.

\section{References}

Aguila, Emma, Alisher R. Akhmedjonov, Ricardo Basurto-Davila, Krishna B. Kumar, Sarah Kups, and Howard J. Shatz. 2012. U.S. Public Opinion on Immigration and the North American Free Trade Agreement. In United States and Mexico: Ties That Bind, Issues That Divide, Ties That Bind, Issues That Divide. Santa Monica: RAND Corporation, pp. 143-48.

Alvaredo, Facundo, Anthony B. Atkinson, Thomas Piketty, and Emmanuel Saez. 2013. The Top 1 Percent in International and Historical Perspective. Journal of Economic Perspectives 27: 3-20. [CrossRef]

Appadurai, Arjun. 1996. Modernity at Large: Cultural Dimensions of Globalization. Minneapolis: University of Minnesota Press.

Babb, Sarah L. 2001. Managing Mexico: Economists from Nationalism to Neoliberalism. Princeton: Princeton University Press. Baiocchi, Gianpaolo. 2016. Popular Democracy: The Paradox of Participation (2016). Stanford: Stanford University Press. Baldwin, Richard. 2016. The Great Convergence. Cambridge: Harvard University Press.

Bandelj, Nina. 2009. The Global Economy as Instituted Process: The Case of Central and Eastern Europe. American Sociological Review 74: 128-49. [CrossRef]

Bandelj, Nina. 2012. Relational Work and Economic Sociology. Politics E Society 40: 175-201. [CrossRef]

Bakker, Matt. 2015. Migrating into Financial Markets: How Remittances Became a Development Tool. Oakland: University of California Press.

Bardhan, Pranab, Samuel Bowles, and Michael Wallerstein. 2006. Globalization and Egalitarian Redistribution. Princeton: Princeton University Press. 
Bauman, Zygmunt. 2010. Globalization: The Human Consequence. Cambridge: Polity Press.

Benyon, John, and David Dunkerley. 2000. Globalization: The Reader. New York: Routledge.

Blair, Tony. 1997. “Leader's Speech, Brighton, 1997”: British Political Speech. Available online: http://www. britishpoliticalspeech.org/speech-archive.htm?speech=203 (accessed on 10 November 2017).

Blendon, Robert J., Logan S. Casey, and John M. Benson. 2017. Public Opinion and Trump's Jobs and Trade Policies. Challenge 60: 228-44. [CrossRef]

Blyth, Mark. 2013. Austerity: The History of a Dangerous Idea. Oxford: Oxford University Press.

Block, Fred L., and Margaret R. Somers. 2014. The Power of Market Fundamentalism: Karl Polanyi's Critique. Cambridge: Harvard University Press.

Bockman, Johanna, and Gil Eyal. 2002. Eastern Europe as a Laboratory for Economic Knowledge: The Transnational Roots of Neoliberalism. The American Journal of Sociology 108: 310-52. [CrossRef]

Bowden, John. 2018. Trump: No 'Political Necessity' to Keep Canada in Nafta Deal. Washington, DC: The Hill, Available online: https://thehill.com/policy/finance/404696-trump-no-political-necessity-to-keep-canada-in-nafta-deal (accessed on 25 April 2020).

Brands, Hal. 2018. American Grand Strategy in the Age of Trump. Washington, DC: Brookings Institution Press.

Camacho-Beltrán, Enrique. 2019. Legitimate Exclusion of Would-Be Immigrants: A View from Global Ethics and the Ethics of International Relations. Social Sciences 8: 19.

Case, Anne, and Angus Deaton. 2020. Deaths of Despair and the Future of Capitalism. Princeton: Princeton University Press.

Castañeda, Jorge G. 2007. Ex Mex: From Migrants to Immigrants. New York: New Press.

Castañeda, Ernesto. 2012. The Indignados of Spain: A Precedent to Occupy Wall Street. Social Movement Studies 11: 309-19. [CrossRef]

Castañeda, Ernesto. 2013. Living in Limbo: Transnational Households, Remittances and Development. International Migration 51: 13-35. [CrossRef]

Castañeda, Ernesto. 2014. The Indignados and Occupy Movements as Political Challenges to Representative Democracy: A Reply to Eklundh. Global Discourse 4: 236-43. [CrossRef]

Castañeda, Ernesto. 2015. The Indignados and the Global Diffusion of Forms of Protest against Authoritarianism and Structural Adjustment Programs. In Waves of Social Movement Mobilizations in the Twenty-First Century: Challenges to the Neo-Liberal World Order and Democracy. Edited by Nahide Konak and Rasim Özgür Dönmez. Lanham: Lexington Books, pp. 11-28.

Castañeda, Ernesto. 2017. Transnationalism in the Lives of Migrants: The Relevance of Znaniecki's Work to Understand Contemporary Migrant Life. In Contemporary Migrations in the Humanistic Coefficient Perspective: Florian Znaniecki's Thought in Today's Science. Edited by Jacek Kubera and Łukasz Skoczylas. Poland: The Florian Znaniecki Scientific Foundation.

Castañeda, Ernesto, and Cathy Lisa Schneider. 2017. Collective Violence, Contentious Politics, and Social Change: A Charles Tilly Reader. New York: Routledge.

Castañeda, Ernesto. 2018a. Understanding Inequality, Migration, Race, and Ethnicity from a Relational Perspective. In Immigration and Categorical Inequality: Migration to the City and the Birth of Race and Ethnicity. Edited by Ernesto Castañeda. New York: Routledge.

Castañeda, Ernesto. 2018b. A Place to Call Home: Immigrant Exclusion and Urban Belonging in New York, Paris, and Barcelona. Stanford: Stanford University Press.

Castañeda, Ernesto. 2018c. A Place to Call Home: Immigrant Exclusion and Urban Belonging in New York, Paris, and Barcelona. Stanford, CA: Stanford University Press.

Castañeda, Ernesto. 2019. Building Walls: Excluding Latin People in the United States. Lanham: Lexington.

Castañeda, Ernesto, and Kevin Beck. 2018. Stigmatizing Immigrant Day Labor: Boundary-Making and the Built-Environment in Long Island, New York. In Immigration and Categorical Inequality: Migration to the City and the Birth of Race and Ethnicity. Edited by Ernesto Castañeda. New York: Routledge.

Castañeda, Ernesto, and Casey Chiappetta. 2020. Border Residents' Perceptions of Crime and Security in El Paso, Texas. Social Sciences 9: 24. [CrossRef]

Castañeda, Ernesto. n.d. Creating Authority over Remittances: Development Experts and the Framing of Remittances as a Development Tool.

Castells, Manuel. 1986. The Rise of the Network Society, the Information Age: Economy, Society and Culture Vol. I. Oxford: Blackwell. 
Castells, Manuel. 1987. The Power of Identity, the Information Age: Economy, Society and Culture Vol. Ii. Oxford: Blackwell.

Castells, Manuel. 1988. End of Millennium, the Information Age: Economy, Society and Culture Vol. Iii. Oxford: Blackwell.

Castells, Manuel. 1999. Information Technology, Globalization and Social Development. New York: United Nations Research Institute for Social Development.

Castles, Stephen, and Alastair Davidson. 2000. Citizenship and Migration: Globalization and the Politics of Belonging. New York: Routledge.

Chatterjee, Partha. 2004. The Politics of the Governed: Reflections on Popular Politics in Most of the World. New York: Columbia University Press.

Chorev, Nitsan. 2007. Remaking U.S. Trade Policy: From Protectionism to Globalization. Ithaca: Cornell University Press.

Clinton, William J. 2000. Remarks at Vietnam National University. The American Presidency Project. Available online: https://www.presidency.ucsb.edu/documents/remarks-vietnam-national-university-hanoi-vietnam (accessed on 30 March 2020).

Crouch, Colin. 2019. The Globalization Backlash. Cambridge: Polity Press.

Czaika, Mathias, and Hein de Haas. 2015. The Globalization of Migration: Hasthe World Become More Migratory? International Migration Review 48: 283-323. [CrossRef]

Davies, William. 2017. The Limits of Neoliberalism: Authority, Sovereignty and the Logic of Competition. London: SAGE Publications.

Della Porta, Donatella. 2006. Globalization from Below: Transnational Activists and Protest Networks. Minneapolis: University of Minnesota Press.

Della Porta, Donatella, and Sidney Tarrow. 2005. Transnational Protest and Global Activism. New York: Rowman and Littlefeld.

Donato, Katharine M., and Douglas S. Massey. 2016. Twenty-First-Century Globalization and Illegal Migration. The ANNALS of the American Academy of Political and Social Science 666: 7-26. [CrossRef]

Doytcheva, Milena. 2020. "White Diversity": Paradoxes of Deracializing Antidiscrimination. Social Sciences 9: 19. [CrossRef]

Duina, Francesco G. 2006. The Social Construction of Free Trade: The European Union, Nafta, and Mercosur. Princeton: Princeton University Press.

Easterly, William Russell. 2006. The White Man's Burden: Why the West's Efforts to Aid the Rest Have Done So Much Ill and So Little Good. New York: Penguin Press.

Ehrenfreund, Max. 2016. What Americans Really Think about Free Trade. Washington Post, March 25.

Eurostat. 2020. Migration and Migrant Population Statistics. Eurostate. Available online: https://ec.europa.eu/ eurostat/statistics-explained/index.php?title=Migration_and_migrant_population_statistics (accessed on 7 April 2020).

Featherstone, Michael. 1990. Global Culture: Nationalism, Globalization and Modernity. London: SAGE Publications.

Felab-Brown, Vanda. 2017. U.S.-Mexican Relations after the Election's Vitriol, Ways to Strengthen a Multifaceted Partnership. In Brookings Big Ideas for America. Edited by Michael O'Hanlon. Washington, DC: Brookings Institution Press, pp. 294-302.

Fridman, Daniel. 2017. Freedom from Work: Embracing Financial Self-Help in the United States and Argentina. Stanford: Stanford University Press.

Feldman, Gregory. 2018. The Gray Zone Sovereignty, Human Smuggling, and Undercover Police Investigation in Europe. Stanford: Stanford University Press.

Fernández-Kelly, María Patricia. 1983. For We Are Sold, I and My People: Women and Industry in Mexico's Frontier. Albany: State University of New York Press.

Fernández-Kelly, Patricia. 2001. Review of The Turbulence of Migration: Globalization, Deterritorialization and Hybridity, Nikos Papastergiadis. Contemporary Sociology 30: 270-71. [CrossRef]

FitzGerald, David, and David Cook-Martín. 2014. Culling the Masses: The Democratic Origins of Racist Immigration Policy in the Americas. Cambridge: Harvard University Press.

Fligstein, Neil. 2001. The Architecture of Markets: An Economic Sociology of Twenty-First-Century Capitalist Societies. Princeton: Princeton University Press.

Flores, René D., and Ariela Schachter. 2018. Who Are the "Illegals"? The Social Construction of Illegality in the United States. American Sociological Review 83: 839-68. [CrossRef] 
Frank, Thomas. 2000. One Market under God: Extreme Capitalism, Market Populism, and the End of Economic Democracy. New York: Doubleday.

Friedman, Thomas L. 1999. The Lexus and the Olive Tree: Understanding Globalization. New York: Farrar, Straus, Giroux. Friedman, Thomas L. 2005. The World Is Flat: A Brief History of the Twenty-First Century. New York: Farrar, Straus and Giroux.

Fukuyama, Francis. 1992. The End of History and the Last Man. New York: Free Press.

Gálvez, Alyshia. 2018. Eating Nafta: Trade, Food Policies, and the Destruction of Mexico. Oakland: University of California Press.

Garip, Filiz. 2017. On the Move: Changing Mechanisms of Mexico-U.S. Migration. Princeton: Princeton University Press. Giddens, Anthony. 1990. The Consequences of Modernity. Cambridge: Polity Press.

Giddens, Anthony. 1999. The Third Way the Renewal of Social Democracy. Malden: Polity Press.

Giddens, Anthony. 2000. The Third Way and Its Critics. Malden: Polity Press.

Golash-Boza, Tanya Maria. 2015. Deported: Immigrant Policing, Disposable Labor, and Global Capitalism. New York: New York University Press.

Google Trends. 2020. Search Interest for Inequality, Climate Change, Migration, and Globalization in the United States. Available online: https://trends.google.com/trends/explore?date=all\&geo=US\&q=inequality, climate $\%$ 20change, migration, globalization (accessed on 31 March 2020).

Hall, Peter A., and David Soskice. 2001. Varieties of Capitalism: The Institutional Foundations of Comparative Advantage. Oxford: Oxford University Press.

Harpaz, Yossi. 2019. Citizenship 2.0: Dual Nationality as a Global Asset. Princeton: Princeton University Press.

Harvey, David. 1989. The Condition of Postmodernity: An Enquiry into the Origins of Cultural Change. Oxford: Blackwell. Harvey, David. 2005. A Brief History of Neoliberalism. Oxford: Oxford University Press.

Hatziprokopiou, Panos. 2002. The Turbulence of Migration: Globalization, Deterritorialization and Hybridity by Nikos Papastergiadis. International Journal of Population Geography 8: 429-32. [CrossRef]

Held, David, Anthony McGrew, David Goldblatt, and Jonathan Perraton. 1999. Global Transformations. Stanford: Stanford University Press.

Hernandez, Ester, and Susan Bibler Coutin. 2006. Remitting Subjects: Migrants, Money and States. Economy and Society 35: 185-208. [CrossRef]

Heyman, Joe. 2018. Immigration or Citizenship? Two Sides of One Social History. In Immigration and Categorical Inequality: Migration to the City and the Birth of Race and Ethnicity. Edited by Ernesto Castañeda. New York: Routledge.

Hochschild, Arlie R. 2016. Strangers in Their Own Land: Anger and Mourning on the American Right. New York: New Press.

Holt, Douglas B, John A Quelch, and Earl L Taylor. 2004. How Global Brands Compete. Harvard Business Review 82: $68-75$.

Horowitz, Juliana M, Ruth Igielnik, and Rakesh Kochha. 2020. Most Americans Say There Is Too Much Economic Inequality in the U.S., but Fewer Than Half Call It a Top Priority. Washington, DC: Pew Research Center. January 9. Available online: https://www.pewsocialtrends.org/2020/01/09/trends-in-income-and-wealthinequality/ (accessed on 31 March 2020).

Hsu, Eric L. 2010. Social Theory and Globalization. In The Routledge Companion to Social Theory. Edited by Anthony Elliott. Abingdon: Routledge, pp. 203-18.

James, Randy. 2009. Mcdonald's Abroad. Time, March 30.

Jiménez, Tomás R. 2017. The Other Side of Assimilation: How Immigrants Are Changing American Life. Oakland: University of California Press.

Johns, Andrew L. 2015. A Companion to Ronald Reagan. Chichester: John Wiley \& Sons.

Jones, Richard C. 2014. The Decline of International Migration as an Economic Force in Rural Areas: A Mexican Case Study. International Migration Review 48: 728-61. [CrossRef]

Jones, Bradley. 2018. Americans Are Generally Positive about Free Trade Agreements, More Critical of Tariff Increases. Washington, DC: Pew Research Center. Available online: http://www.pewresearch.org/fact-tank/2018/05/10/americans-are-generally-positive-about-free-tradeagreements-more-critical-of-tariff-increases/ (accessed on 25 April 2020).

Kalleberg, Arne L. 2011. Good Jobs, Bad Jobs: The Rise of Polarized and Precarious Employment Systems in the United States, 1970s-2000s. New York: Russell Sage Foundation. 
Karabell, Zachary. 2009. Superfusion: How China and America Became One Economy and Why the World's Prosperity Depends on It. New York: Simon \& Schuster.

Keister, Lisa A. 2014. The One Percent. Annual Review of Sociology 40: 347-67. [CrossRef]

Killewald, Alexandra, Fabian T. Pfeffer, and Jared N. Schachner. 2017. Wealth Inequality and Accumulation. Annual Review of Sociology 43: 379-404. [CrossRef] [PubMed]

King, Marissa. 2020. Social Chemistry: Decoding the Patterns of Human Connection. New York: Dutton.

Klare, Michael T. 1992. We Must Hear the Third World. Progressive 56: 19-21.

Koopmans, Ruud. 2009. Trade-Offs between Equality and Difference: Immigrant Integration, Multiculturalism and the Welfare State in Cross-National Perspective. Journal of Ethnic and Migration Studies 36: 1-26. [CrossRef]

Koos, Agnes Katalin, and Kenneth Keulman. 2019. Methodological Nationalism in Global Studies and Beyond. Social Sciences 8: 20. [CrossRef]

Korte, Gregory, and Alan Gomez. 2018. Trump Ramps up Rhetoric on Undocumented Immigrants: 'These Aren't People. These Are Animals. USA Today, May 17.

Koser, Khalid. 2007. International Migration: A Very Short Introduction. Oxford: Oxford University Press.

Krippner, Greta. 2012. Capitalizing on Crisis: The Political Origins of the Rise of Finance. Cambridge: Harvard University Press.

Lang, Michael. 2006. Globalization and Its History. The Journal of Modern History 78: 899-931. [CrossRef]

Laws, Glenda. 1997. Globalization, Immigration, and Changing Social Relations in U. S. Cities. The ANNALS of the American Academy of Political and Social Science 551: 89-104. [CrossRef]

Levitt, Theodore. 1983. The Globalization of Markets. Harvard Business Review 61: 92-102.

MacKenzie, Donald A., Fabian Muniesa, and Lucia Siu. 2007. Do Economists Make Markets? On the Performativity of Economics. Princeton: Princeton University Press.

Maddux, Thomas R. 2005. Ronald Reagan and the Task Force on Immigration. Pacific Historical Review 74: 195-236. [CrossRef]

Massey, Douglas S. 2019. Today's Us-Mexico ‘Border Crisis' in 6 Charts. The Conversation. Available online: http://theconversation.com/todays-us-mexico-border-crisis-in-6-charts-98922 (accessed on 25 April 2020).

McAndrews, Lawrence J. 2015. Refuge in Lord: Bill Clinton 1993-2001. Washington, DC: Catholic University of American Press.

McKevitt, Andrew. 2018. Donald Trump Has Been Wrong on Trade for 30 Years. Washington Post, July 30.

Miller-Idriss, Cynthia. 2017. The Extreme Gone Mainstream: Commercialization and Far Right Youth Culture in Germany. Princeton: Princeton University Press.

Mische, Ann. 2011. Relational Sociology, Culture, and Agency. In The Sage Handbook of Social Network Analysis. Edited by John Scott and Peter J. Carrington. London: Sage Publications, pp. 80-97.

Ngai, Mae M. 2004. Impossible Subjects: Illegal Aliens and the Making of Modern America. Princeton: Princeton University Press.

O'Sullivan, John. 2016a. The Changing Face of Global Trade. The Economist, November 23.

O'Sullivan, John. 2016b. Globalisation Backlash 2.0. The Economist, November 23.

O'Sullivan, John. 2017. The Globalisation Counter-Reaction. The Economist, June 14.

Oliver, Craig. 2016. Unleashing Demons: The Inspiration Behind Channel 4 Drama Brexit: The Uncivil War. London: Hodder \& Stoughton.

Overbeek, Henk. 1995. Towards a New International Migration Regime: Globalization, Migration and the Internationalization of the State. In Miigration and European Integration: The Dynamics of Inclusion and Exclusion. Edited by Robert Miles and Dietrich Thränhardt. London: Pinter.

Padgett, John F., and Christopher K. Ansell. 1993. Robust Action and the Rise of the Medici, 1400-1434. American Journal of Sociology 98: 1259-319. [CrossRef]

Papastergiadis, Nikos. 2000. The Turbulence of Migration: Globalization, Deterritorialization and Hybridity. Cambridge: Polity Press.

Passel, Jeffrey, D’Vera Cohn, and Ana Gonzalez-Barrera. 2012. Net Migration from Mexico Falls to Zero-And Perhaps Less. Washington, DC: Pew Research Center.

Piketty, Thomas. 2014. Capital in the 21st Century. Cambridge: Harvard University Press.

Piketty, Thomas, and Emmanuel Saez. 2003. Income Inequality in the United States, 1913-1998. The Quarterly Journal of Economics 118: 1-41. [CrossRef] 
Poppi, Franca, and Winnie Cheng. 2013. The Three Waves of Globalization: Winds of Change in Professional, Institutional and Academic Genres. Cambridge: Cambridge Scholars Publishing.

Portes, Alejandro. 1997. Neoliberalism and the Sociology of Development: Emerging Trends and Unanticipated Facts. Population and Development Review 23: 229-59. [CrossRef]

R., C. 2013. When Did Globalisation Start? The Economist, September 23.

Radford, Jynnah. 2019. Key Findings about U.S. Immigrants. Washington, DC: Pew Research Center, Available online: https://www.pewresearch.org/fact-tank/2019/06/17/key-findings-about-u-s-immigrants/ (accessed on 25 April 2020).

Raithelhuber, Eberhard, Nandita Sharma, and Wolfgang Schröer. 2018. The Intersection of Social Protection and Mobilities: A Move Towards a 'Practical Utopia' Research Agenda. Mobilities 13: 685-701. [CrossRef]

Reagan, Ronald. 1981. Remarks at the Annual Meeting of the Boards of Governors of the World Bank Group and International Monetary Fund. The American Presidency Project. Available online: http://www.presidency. ucsb.edu/ws/?pid=44311 (accessed on 13 November 2017).

Reagan, Ronald. 1988. Remarks and a Question-and-Answer Session with Members of the City Club of Cleveland, Ohio. The American Presidency Project. Available online: http://www.presidency.ucsb.edu/ws/?pid=35502 (accessed on 13 November 2017).

Reich, Robert B. 1997. Locked in the Cabinet. New York: Knopf.

Robertson, Roland. 1987a. Globalization and Societal Modernization: A Note on Japan and Japanese Religion. Sociological Analysis 47: 35-43. [CrossRef]

Robertson, Roland. 1987b. Globalization Theory and Civilization Analysis. Comparative Civilizations Review 17: 20-30.

Rodrik, Dani. 1997. Has Globalization Gone Too Far? Washington, DC: Institute for International Economics.

Rodrik, Dani. 2007. One Economics, Many Recipes: Globalization, Institutions, and Economic Growth. Princeton: Princeton University Press.

Rung, Daile Lynn. 2020. Processes of Sub-Citizenship: Neoliberal Statecrafting 'Citizens,' 'Non-Citizens,' and Detainable 'Others'. Social Sciences 9: 30. [CrossRef]

Salganik, Matthew J. 2018. Bit by Bit: Social Research in the Digital Age. Princeton: Princeton University Press.

Salzinger, Leslie. 2003. Genders in Production: Making Workers in Mexico's Global Factories. Berkeley: University of California Press.

Sanderson, Matthew R., and Jeffrey D. Kentor. 2009. Globalization, Development and International Migration: A Cross-National Analysis of Less-Developed Countries, 1970-2000. Social Forces 88: 301-36. [CrossRef]

Sassen, Saskia. 1988. The Mobility of Labor and Capital: A Study in International Investment and Labor Flow. Cambridge: Cambridge University Press.

Sassen, Saskia. 1998. Globalization and Its Discontents: Essays on the New Mobility of People and Money. New York: New Press.

Sassen, Saskia. 2001. The Global City: New York, London, Tokyo. Princeton: Princeton University Press.

Sassen, Saskia. 2007. Sociology of Globalization. New York: W.W. Norton.

Sawhill, Isabel. 2018. The Forgotten Americans: An Economic Agenda for a Divided Nation. New Haven: Yale University Press.

Sennett, Richard. 1998. The Corrosion of Character: The Personal Consequences of Work in the New Capitalism. New York: Norton.

Sennett, Richard. 2003. Respect in a World of Inequality. New York: W.W. Norton.

Sennett, Richard. 2006. The Culture of the New Capitalism. New Haven: Yale University Press.

Sennett, Richard, and Jonathan Cobb. 1993. The Hidden Injuries of Class. New York: Norton.

Shipman, Tim. 2016. All out War: The Full Story of How Brexit Sank Britain's Political Class. London: HarperCollins Publishers.

Short, Robert, and Lisa Magaña. 2002. Political Rhetoric, Immigration Attitudes, and Contemporary Prejudice: A Mexican American Dilemma. Journal of Social Psychology 142: 701-12. [CrossRef]

Simmel, Georg. 1964. Conflict $\mathcal{E}$ the Web of Group Affiliations. New York: Free Press.

Slobodian, Quinn. 2018. Globalists: The End of Empire and the Birth of Neoliberalism. Cambridge: Harvard University Press.

Stiglitz, Joseph E. 2003a. The Roaring Nineties: A New History of the World's Most Prosperous Decade. New York: W. W. Norton \& Co. 
Stiglitz, Joseph E. 2003b. Globalization and Its Discontents. New York: W.W. Norton.

Strange, Susan. 1986. Casino Capitalism. Oxford: Basil Blackwell.

The Economist. 1997. One World? The Economist, October 16.

The Economist. 2006. The Rich, the Poor and the Growing Gap between Them. The Economist, June 15.

The Economist. 2008. A Bigger World. The Economist, September 18.

The Economist. 2009. Going Global. The Economist, November 5.

The Economist. 2016. The Third Wave of Globalisation May Be the Hardest: First Free Movement of Goods, Then Ideas. But Momentum May Stop at the Free Exchange of People. The Economist, November 19.

Tilly, Charles. 1995. Globalization Threatens Labor's Rights. International Labor and Working-Class History 47: 1-23. [CrossRef]

Tilly, Charles. 2005. Identities, Boundaries, and Social Ties. Boulder: Paradigm Publishers.

Tilly, Charles, and Ernesto Castañeda. 2007. Class Notes for Revolutions, Social Movements, and Contentious Politics. New York: Columbia University.

Tilly, Charles, Jeff Goodwin, and Mustafa Emirbayer. 1995. The Relational Turn in Macrosociology: A Symposium. In Center for Studies of Social Change. New York: Center for Studies of Social Change, New School for Social Research.

Tilly, Charles, Ernesto Castañeda, and Lesley J Wood. 2020. Social Movements, 1768-2018. New York: Routledge.

Todd, Zoe. 2019. By the Numbers: Syrian Refugees around the World. Available online: https://www.pbs.org/ wgbh/frontline/article/numbers-syrian-refugees-around-world/ (accessed on 7 April 2020).

Trump, Donald. 2016a. Donald Trump's Republican Convention Speech, Annotated. NPR. Available online: https://www.npr.org/2016/07/21/486883610/fact-check-donald-trumps-republican-conventionspeech-annotated (accessed on 31 March 2020).

Trump, Donald. 2016b. Declaring America's Economic Independence. Washington, DC: Politico, Available online: https: //www.politico.com/story/2016/06/full-transcript-trump-job-plan-speech-224891 (accessed on 1 April 2020).

Trump, Donald. 2018. Mexico Is Making a Fortune on Nafta. Available online: https:/twitter.com/realdonaldtrump/ status/980794173279342592. (accessed on 25 April 2020).

Tucker, Robert, ed. 1978. The Marx-Engels Reader. New York: W. W. Norton.

UN. 2017. "Population Facts": United Nations ECOSOC. Available online: https://www.un.org/en/development/ desa/population/publications/pdf/popfacts/PopFacts_2017-5.pdf (accessed on 7 April 2020).

Valeriano, Lourdes Lee, and Joann S. Lublin. 1991. U.S. Immigration Law Should Ease Inflow of Talent for Businesses, but Has Snags, Too. In Wall Street Journal. New York: Wall Street Journal.

van der Waal, Jeroen. 2013. Foreign Direct Investment and International Migration to Dutch Cities. Urban Studies 50: 294-311. [CrossRef]

Van Hook, Jennifer, and Frank D. Bean. 2009. Explaining Mexican Immigrant Welfare Behaviors: The Importance of Employment-Related Cultural Repertoires. American Sociological Review 74: 423-44. [CrossRef]

Vertovec, Steven. 2007. Super-Diversity and Its Implications. Ethnic and Racial Studies 30: 1024-54. [CrossRef]

Vogel, Steven K. 1996. Freer Markets, More Rules: Regulatory Reform in Advanced Industrial Countries. Cornell: Cornell University Press.

Wallerstein, Immanuel. 1979. The Capitalist World-Economy. Cambridge: Cambridge University Press.

Watts, Duncan J. 2003. Six Degrees: The Science of a Connected Age. New York: Norton.

Weisbrot, Mark, Dean Baker, Egor Kraev, and Judy Chen. 2001. The Scorecard on Globalization 1980-2000: Twenty Years of Diminished Progress. Washington, DC: Center for Economic and Policy Research. Available online: https://cepr.net/documents/publications/globalization_2001_07_11.pdf (accessed on 30 March 2020).

Wood, Lesley J. 2008. Breaking the Wave: Repression, Identity, and Seattle Tactics. Mobilization: An International Quarterly 12: 377-88. [CrossRef]

Wood, Lesley J. 2012. Direct Action, Deliberation, and Diffusion: Collective Action after the Wto Protests in Seattle. Cambridge: Cambridge University Press.

Young, Gloria “Gay”. 2015. Gendering Globalization on the Ground: The Limits of Feminized Work for Mexican Women's Empowerment. New York: Routledge.

Zelizer, Viviana A. 2012. How I Became a Relational Economic Sociologist and What Does That Mean? Politics $\mathcal{E}$ Society 40: $145-74$. 
Zlotnik, Hania. 1999. Trends of International Migration since 1965: What Existing Data Reveal. International Migration 37: 21-61. [CrossRef]

Zolberg, Aristide R. 2006. A Nation by Design: Immigration Policy in the Fashioning of America. New York: Russell Sage Foundation, Cambridge: Harvard University Press.

(C) 2020 by the authors. Licensee MDPI, Basel, Switzerland. This article is an open access article distributed under the terms and conditions of the Creative Commons Attribution (CC BY) license (http://creativecommons.org/licenses/by/4.0/). 